\title{
Calidad y mestizaje en los padrones de vecinos de San Luis del Caney y Santiago de Cuba (1775-1800)
}

\author{
María de los Ángeles Meriño Fuentes \\ Aisnara Perera Díaz \\ Seminario Permanente Hispano-Cubano de Historia \\ de la Familia y Cambio Social, \\ Instituto de Investigación Cultural Juan Marinello, La Habana
}

Recibido: mayo de 2014

Aprobado: septiembre de 2014

Resumen: En el artículo se analizan los intereses de los proyectos económicos de la elite que mediaron en la construcción de los padrones coloniales en el poblado indio de San Luis del Caney y la ciudad de Santiago de Cuba en los últimos treinta años del siglo XVIII, interesándonos, ante todo, demostrar cómo la intervención de los empadronadores que cumplían "aparentemente" con el objetivo dispuesto, desde cierta voluntad "extra" demográfica, influyó en la manipulación de la categoría calidad-color tanto en el proceso de identificación de los residentes del poblado indio con el fin de negar su existencia como grupo privilegiado como en el de las familias santiagueras que se habían propuesto el blanqueamiento como estrategia de movilidad social.

Palabras claves: padrones de vecinos, familia, hogar, calidad, color, siglo XviII, Cuba.

\section{Quality and miscegenation in the registers of residents of San Luis de el Caney and Santiago de Cuba (1775-1800)}

\begin{abstract}
In the article the interests of the elite population economical projects that mediated in the construction of the colonial censuses are analyzed taking into account the Cuban's native indian town called San Luis del Caney and the city of Santiago de Cuba, during the last thirty years of the 18th-century. From there we are interested on demonstrating how the intervention of the census takers that "seemingly" fullfilled the disposed objective from a certain "extra" demographic willigness influenced in the manipulation of the category quality-color as much in the process of identification of the residents of the Indian town aiming at denying its existence as a privileged group as in
\end{abstract}


that of the families from the city of Santiago de Cuba that had proposed themselves to be white skin as a strategy of social mobility above all.

Key words: neighbors censuses, family, home, quality, color, 18th-century, Cuba.

\section{Presentación}

La Cuba colonial de los últimos cuarenta años del siglo XVIII fue testigo de un movimiento sin precedentes en cuanto a la elaboración de padrones de vecinos en las más importantes localidades de la isla. Así, desde 1761 hasta 1800, tanto sus habitantes como su riqueza agrícola constituyeron el centro de innumerables registros en unos casos por iniciativa de los gobernadores -el padrón del Departamento Oriental de 1761- de los capitanes generales -el de 1766 y 17741775- por orden de la Corona -los levantados en 1777-1778-los realizados por interés de los Ayuntamientos locales -los de Santiago de Cuba de 1797 y 1800$\mathrm{y}$ finalmente, los generados por los intereses fiscales de la iglesia para el cobro de las rentas decimales en las jurisdicciones eclesiásticas entre 1780 y $1799 .{ }^{1}$

Este notable acervo documental ha sido empleado con regularidad por los historiadores cubanos y foráneos, ${ }^{2}$ sin embargo debemos admitir que, en la mayoría de los casos, su explotación se ha limitado a lo estrictamente demográfico -mostrándosenos, por ejemplo, en el trabajo del investigador José Novoa Betancourt "Haciendas ganaderas en Holguín, 1545-1867" el reflejo de la peculiar organización agraria de dicha región en los padrones y censos, ${ }^{3}$ o el lento desarrollo de la estructura económica y poblacional del Oriente cubano que nos propone la historiadora Olga Portuondo Zúñiga en su "Estudio demográfico del

\footnotetext{
${ }^{1}$ La descripción y referencias para la consulta de la mayoría de estos padrones se encuentran en Gloria García, Violeta Serrano, Irma Tamayo y Alejandrino Borroto, Fuentes estadísticas para la historia económica y social de Cuba (1760-190o), La Habana, Ed. Academia, 1987, pp.3-18.

2 Ver el interesante empleo que hace de los padrones santiagueros del siglo XVIII y XIX en su tesis doctoral la historiadora española Lucía Provencio Garrigo, Sobre la construcción de género: mujeres, sociedad y educación en Santiago de Cuba, 1778-1868, Tesis doctoral, Universidad de Murcia, 2002. [Cd-rom]

3 José Novoa Betancourt, Haciendas ganaderas en Holguín, 1545-1867, Holguín, Ed. Holguín, 2008.
} 
Departamento Oriental. Siglos XVI-XIX (hasta 1868)". ${ }^{4}$ Menos atención, sin embargo, han recibido por parte de los historiadores sociales los padrones o listas nominativas de vecinos del siglo XVIII como textos donde se "construía" y "negociaba" la asignación de la calidad-color. De tal suerte que solo se analizan los datos cual si fuesen reflejo fiel de una realidad que se supone inmutable y libre de conflicto; así, más allá de saber cuál era en determinados momentos la proporción de un grupo -blancos de origen europeo- con respecto a otros -pardos y morenos descendientes de africanos- no se aprovecha la oportunidad para interiorizar sobre las dinámicas generadas a partir de la producción de los datos. Por no mencionar que se reflexiona bien poco sobre la intención de ocultamiento de los llamados indocubanos, grupo de individuos que, desde sus contemporáneos hasta los historiadores de los siglos XVIII y XIX,, 5 suponen mezclados y/o mestizados con blancos y negros y, por tanto, inexistentes.

De igual forma -aun cuando han sido tomados en cuenta para la definición de la sociedad colonial cubana como estamental y de castas -6 resulta notable la ausencia de discusión sobre la terminología empleada por los funcionarios encargados del levantamiento de los padrones. De tal manera, los autores que se han pronunciado al respecto valoran acertadamente que fueron las diferencias raciales la base de la estratificación: "el ordenamiento social mucho más rígido se consagra desde mediados del siglo XvIII", ${ }^{7}$ nos refiere la citada Portuondo Zúñiga pues, en verdad, en la propia medida en que la economía de la isla comenzó a basarse en el trabajo esclavo y el número de dicha fuerza laboral creció, se produjo tanto un reforzamiento de los privilegios concedidos a los blancos como la consolidación -sobre todo en los padrones realizados por interés de las autoridades locales- de las fronteras deliberadamente trazadas para separar a los llamados "libres de color" en grupos diferenciados de pardos/mulatos y more-

\footnotetext{
4 Olga Portuondo Zúñiga, "Estudio demográfico del Departamento Oriental. Siglos XVI-XIX (hasta 1868)", en Olga Portuondo Zúñiga, El Departamento Oriental. 1510-1868: dos temas de historia económica, Santiago de Cuba, Ed. Santiago, 2012, pp.31-107.

${ }^{5}$ Luis Alejandro Baralt, “Apuntes históricos del pueblo de indios de San Luis de los Caneyes”, en Emilio Bacardí, Crónicas de Santiago de Cuba, tomo II, Barcelona, Tip. Carbonel y Esteva, 1909, pp.7-18.

${ }^{6}$ Jorge Ibarra Cuesta, "Del sentimiento de patria a la conciencia de nación (1600 y 1868)", en Jorge Ibarra Cuesta, Patria, etnia y nación, La Habana, Ed., Ciencias Sociales, 2007, pp.21-25.

7 O. Portuondo Zúñiga, “Estudio demográfico del Departamento Oriental”, p.36.
} 
nos/negros. Siendo justo precisar que la generalidad se levantó casa por casa pero eso sí, siempre con la indicación de cuál era "casa de blanco" y cuál de "pardo/mulato o negro/moreno" - y calle tras calle y que tal metodología no implicó, al menos en dicho período, la existencia de "barrios segregados" en las ciudades cubanas. ${ }^{8}$ En todo caso lo significativo a destacar en muchas poblaciones de la isla es que la distribución de sus habitantes se realizó acorde con los recursos económicos poseídos y su pertenencia a la elite local o a los sectores más desposeídos; pudiéndose afirmar, por ejemplo, que en el Santiago de Cuba de entonces no existían barrios enteramente "negros" pero sí barrios habitados mayoritariamente por personas pobres de todos los colores.

Teniendo en cuenta entonces la escasa producción historiográfica cubana con relación al estado actual de los estudios realizados en otros países de América Latina y el Brasil y considerando cómo entre los estudiosos de la isla cuesta todavía superar lo que el historiador colombiano Sergio Paolo Solano gusta referir como período de "lectura ingenua de los censos y de las categorías socioraciales", ${ }^{9}$ nos propusimos, en nuestro libro Familias, agregados y esclavos: los padrones de vecinos de Santiago de Cuba (1778-1861) publicado en el 2011 además de analizar el agrupamiento familiar, la posesión de esclavos y la presencia de agregados en los hogares ${ }^{10}$ así como el examen de la asignación de la calidad-color como evidencia de las estrategias de movilidad social de las familias y del control ejercido sobre la población con ascendencia africana. Advertíamos entonces -sin olvidar que para algunos estudiosos la estratificación social resulta integradora de una "diversidad de factores tales como la "raza", la posición económica, la ocupación, el estilo de vida, los lazos de parentesco, las redes sociales a que se perteneciera [y] el sitio de vivienda"-11 que los empadronadores del siglo XVIII conminados a clasificar a los residentes en las ciudades y

\footnotetext{
8 J. Ibarra, "Del sentimiento de patria a la conciencia de nación", p.26.

9 Sergio Paolo Solano, "Padrones de población e historiografía sobre la configuración socioracial hispanoamericana del siglo XviII", en El Taller de la Historia vol.5, n. ${ }^{\circ}$ 5, Cartagena, Universidad de Cartagena, 2013, p.125.
}

10 María de los Ángeles Meriño Fuentes y Aisnara Perera Díaz, Familias, agregados y esclavos. Los padrones de vecinos de Santiago de Cuba (1778-1861), Santiago de Cuba, Ed. Oriente, 2011.

${ }^{11}$ Patrick J. Carroll, "El debate académico sobre los significados sociales entre clase y raza en el México del siglo XVIII", pp.111-142. Citado por S. P. Solano, "Padrones de población e historiografía", p.127. 
en los campos según la calidad, asumieron aquella cual sinónimo de "color" -de hecho en 1783 las indicaciones transmitidas por la capitanía general en un formulario para empadronar a los residentes en los pueblos especificaban que el "color" fuese registrado únicamente con relación a los criados libres-12 indicador decisivo - unas veces desde el disfrute de determinadas prerrogativas y otras desde su exclusión del ejercicio de actividades profesionales y de estudios superiores- para su ubicación en la jerarquía social. De hecho, hacia 1800 en Santiago de Cuba algunos funcionarios empleaban la categoría "clase" como equivalente a "calidad", la que desapareció del lenguaje estadístico solo hacia mediados de la década del treinta del siglo XIX, sin dudas porque ambos vocablos aludían a la organización socio clasista que se inspiraba tanto en el origen como en el color de la piel.

Así, basaremos nuestra hipótesis y, por tanto, nuestras reflexiones, en mostrar cómo en la producción de los padrones del pueblo indio de San Luis del Caney y de algunos cuarteles de la ciudad de Santiago de Cuba entre 1775 y 1800 influyeron, los intereses de la elite blanca local para transformar en instrumento de dominación económica e ideológica un mecanismo concebido, desde el poder metropolitano, para el conocimiento de la población en cuanto a su número, calidad y ocupación económica. De ahí que nuestra lectura se focalice, básicamente, en cómo resultaban catalogadas las familias y sus miembros dadas las funciones ideológicas de las calidades asignadas acorde a los intereses de las clases dominantes en momentos de conflictos sociales y a las variaciones que las mismas sufrieron con el tiempo a partir del despliegue de estrategias de movilidad social. En tal sentido, la identificación nominal y la reconstrucción genealógica nos permitirá revelar la "política" de los empadronadores en cuanto a la asignación de la calidad-color y las manipulaciones realizadas por aquellos bajo las contingencias de los tiempos. Adoptando, por tanto, como metodología de trabajo, a la vez que los conceptos de:

Familia: la que constituye una pareja, casada o en unión consensual, con sus hijos, solteros, sin descendencia y al abrigo de sus padres; también hombres o mujeres solteros con sus hijos, así como viudos o viudas con sus hijos..$^{13}$

\footnotetext{
12 Archivo Nacional de Cuba, (La Habana Cuba), (ANC) Fondo Gobierno General, legajo 490, n. ${ }^{\circ}$ 24.150.

${ }^{13}$ M. Meriño y A. Perera, Familias, agregados y esclavos, p.27.
} 
Hogar: el conjunto de individuos que conviven bajo un mismo techo y mantienen lazos de parentesco o subordinación entre sí, bajo la autoridad del llamado jefe de hogar, siendo este el individuo que encabeza la relación de residentes y que puede o no ser el jefe de familia. ${ }^{14}$

Calidad: vista desde la clasificación fenotípica e integral como [...] el color de la piel y la forma del cabello [...] más a menudo empleadas para determinar la casta (y el estamento) a que pertenecía un individuo durante la época colonial (considerándose) la característica más fácilmente apreciable y aquella en que podía cimentarse una buena clasificación (al mostrar) una herencia racial supuesta o real, un prestigio social por derivación y una diferenciación de status. ${ }^{15}$

Padrón de vecinos: nómina o lista que se hace en las ciudades, villas y lugares para saber el número de sus habitantes, su nombre, edad, sexo y otras cir-

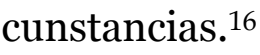

El análisis longitudinal de los núcleos constituidos por dichas familias y hogares residentes en las unidades habitacionales registradas en los padrones que, enriquecidos con el cruzamiento de fuentes, nos permitirá evidenciar complejidades y dinámicas que rompen el estatismo atribuido a las listas nominativas de vecinos.

Nuestro ensayo se estructura, por tanto, en tres secciones fundamentales: una reseña general de la historia de ambas localidades desde sus respectivos actos fundacionales hasta el momento de la realización de los padrones examinados, el análisis de los empadronamientos del pueblo de El Caney y su área rural entre 1775 y 1778 así como la incidencia que tuvo en los mismos el interés

\footnotetext{
${ }^{14}$ M. Meriño y A. Perera, Familia, agregados y esclavos, p.27.

15 Definición elaborada a partir de las seis perspectivas -como concepto sociocultural, como categoría socioeconómico, como estratificación clasista, como un sistema complejo de representación social, como clasificación fenotípica y, finalmente, como concepto integral- que sobre el significado y conformación de la calidad étnica comenta el profesor David Carvajal López en su exhaustiva investigación sobre el mestizaje en una parroquia michoacana, ver David Carvajal López, La población en Bolaños, 1740-1848: dinámica demográfica, familia y mestizaje, Zamora, El Colegio de Michoacán, 2009, pp.82-83.

16 Marcelo Martínez Alcubilla, Diccionario de la Administración española, peninsular y ultramarina, t. X, Madrid, Imprenta de la Sra. V. e Hijas de A. Pañuelas, 1869, p.640.
} 
por el acceso a las tierras de la reserva india y, por último, el examen de los padrones realizados en algunos de los barrios de la ciudad de Santiago de Cuba en 1778 y 1800 con el fin de observar cómo la metodología de recolección de los datos y la asignación de calidades cumplió tanto una función de control social como de negociación del status a medida que la estructura demográfica de la urbe se mostró favorable a los llamados "de color", libres y esclavos.

\section{Santiago de Cuba y San Luis del Caney: historias paralelas}

La villa de Santiago de Cuba fue erigida, al fondo de una gran bahía en la costa sur de la Gran Antilla, en el último de los actos fundacionales emprendidos por el conquistador y adelantado Diego Velásquez y Cuellar, en el verano de $1515 .{ }^{17}$ Al poco tiempo -1522-recibía el título de ciudad, trasladándose hacia ella, la sede del obispado y del gobierno civil de la isla; acciones fundamentadas en la organización y abastecimiento de las expediciones que iniciaron la conquista de la América continental. ${ }^{18}$ Fue así mismo, uno de los dos centros administrativos en que quedó dividido, en 1607, el territorio insular. Como toda ciudad colonial hispana, su trazado se acogió a un modelo pre establecido, que situaba en su centro, una plaza de armas, alrededor de la cual se ubicaban los edificios representativos de los poderes civiles y religioso: casa del cabildo, palacio del gobernador e iglesia catedral; y en los solares más próximos, las casas edificadas por los fundadores, de modo que la cercanía al centro -transmitida de generación a generación entre las más rancias familias criollas- fue símbolo de preeminencia y distinción. ${ }^{19}$ A partir de este eje político-administrativo se trazaron las calles

\footnotetext{
17 Leo Cesar Miranda Saborit, Santiago de Cuba (1515-1550), Santiago de Cuba, Ed. Oriente, 1995, pp.7-18.

${ }^{18}$ Olga Portuondo Zúñiga, Santiago de Cuba desde su fundación hasta 1868, Santiago de Cuba, Ed. Oriente, 1996, p.8.

${ }^{19} \mathrm{El}$ acto de fundación de cualquier villa o ciudad estaba revestido de gran solemnidad. Después que se señalaban los sitios que ocuparían la plaza, iglesia y casa del gobernador, se repartían los solares y los indios que cada fundador recibiría en encomienda. Sobre este primer momento de la historia santiaguera no existen testimonios pues la relación del adelantado Diego Velázquez no se detuvo en estos detalles. Es muy probable que el fundador haya procedido, como lo hizo en 1535, Francisco Pizarro durante la fundación de Lima: "señaló a cada uno de los conquistadores y pobladores encomenderos un solar, de las cuadras más cercanas a la Plaza, en que edificasen
} 
que, no obstante la aspiración - por parte de los gestores del proyecto- de obtener cuadrículas perfectas, resultaron, desde la topografía del terreno, una consecución de manzanas irregulares, estrechas y quebradas, trazadas entre pendientes difíciles de empedrar.

Con respecto a su población, contaba el reducido núcleo urbano de Santiago de Cuba hacia finales de la sexta década de su historia con solo treinta vecinos y -según el obispo Juan del Castillo tras su visita pastoral realizada a la diócesis- con la existencia -quizás con posterioridad a 1551- de un "caserío de indios" ocupado por 20 naturales nombrado los Caneyes en clara alusión a las típicas construcciones aborígenes y establecido en un paraje saludable, de fértiles tierras y abundante aguada, a unos cuatro kilómetros de la capital de la entonces isla Fernandina. ${ }^{20}$ La formalización del núcleo indígena en el Oriente cubano demoraría, sin embargo, algunos años, en principio porque los ahora vasallos de los católicos monarcas se resistieron a residir de manera permanente cerca de sus opresores, de ahí que el proceso de "convencer" a los naturales de los beneficios de vivir agrupados fuera a largo plazo y no exento de violentos conflictos. ${ }^{21}$ Siendo muestra el lento crecimiento poblacional de las dificultades que debieron encontrar los españoles -autorizados en 1563 a usar la fuerza contra los núcleos de resistencia que habían formado en alianza con esclavos fugitivos- para el definitivo establecimiento del pueblo.

sus casas, a algunos de los más beneméritos dio dos solares; y demás de estos que señaló para casa de su vivienda, como todavía quedaban dentro de la tierra muchas cuadras vacías, les dio otros muchos solares para huertas y ranchos de los indios de su servicio”, José Ramón Jouve Martín, Esclavos de la ciudad letrada. Esclavitud, escritura y colonialismo en Lima (16501700), Lima, Instituto de Estudios Peruanos, 2005, p.26.

${ }^{20}$ Las referencias más fiables sobre el origen del pueblo indican que su establecimiento se debió producir con posterioridad a 1551 pues fue en dicho año que las autoridades de la isla se vieron obligadas a dar cumplimiento a las llamadas Leyes Nuevas de 1542 que declaraba exentos de esclavitud a los naturales -tanto a los oriundos de la isla como a los aquí traídos desde otros territorios en calidad de esclavos- al abolir las encomiendas y declararlos vasallos de la corona española. No obstante, digamos que la historia oficial del poblado celebra como fecha fundacional 1539. Por nuestra parte, optamos por el criterio aquí expuesto que corresponde al arqueólogo e historiador santiaguero Juan Manuel Reyes Cardero, ratificándose, por entonces, las diversas órdenes que, desde el inicio de la conquista de La Española, se habían dado para "la reducción de los naturales a pueblos y la creación en ellos de repúblicas municipales al estilo español.” pp.234-235.

${ }^{21}$ Se afirma que al abolirse las encomiendas muchos indios se refugiaron en los bosques. 
Tabla 1: Habitantes de la ciudad de Santiago de Cuba y del pueblo indio del Caney en 1604

\begin{tabular}{|l|c|c|c|c||}
\hline \multirow{2}{*}{ Poblaciones } & Vecinos & Esclavos & Poblaciones & Vecinos \\
\cline { 2 - 5 } & Hombres & Mujeres & Hombres & Mujeres \\
\hline Santiago de Cuba & 205 & 129 & 131 & 98 \\
\hline El Caney & 41 & 37 & --- & --- \\
\hline
\end{tabular}

Fuente: Elaboración propia. Archivo General de Indias, Santo Domingo, legajo 150.*

Las cifras sugieren que el núcleo urbano santiaguero no se había recuperado de la crisis iniciada tras la salida de los vecinos que se unieron a las expediciones de conquistas y/o emigraron hacia otras villas con mejores perspectivas de desarrollo en la propia isla. No obstante, la preeminencia simbólica de Santiago de Cuba fue respetada cuando en 1607 la corona decidió dividir el territorio insular en dos Departamentos: el Occidental cuya capital era La Habana y el Oriental con Santiago de Cuba como sede.

Resultando bien distinta a lo imaginado desde España la realidad para los residentes en El Caney si tomamos como punto de partida las normas dictadas por la metrópolis en 1618 para organizar los pueblos de indios en la América española con el objetivo de que aquellos pudieran contar con "aguas, tierras y montes, entradas y salidas y labranzas y un ejido de una legua de largo, donde los indios puedan tener sus ganados, sin que se revuelvan con otros españoles", 22 oficializándose incluso para 1629 la existencia de un Ayuntamiento indio con la elección de un alcalde, cargo que recaía en el individuo aceptado por la comunidad como cacique, y tres regidores. Aún así, en 1655 no se habían deslindado todavía los terrenos propios de la comunidad, situación aprovechada por los residentes en Santiago de Cuba para fomentar estancias de cultivos, vegas y trapiches en los fértiles predios caneyenses; usurpaciones que, según el cacique Marcos Rodríguez, llegaban hasta las cercanías del poblado no quedan-

\footnotetext{
* Observación: en el campo se registraron 12 hombres blancos en hatos y corrales y 7 hombres y una mujer esclavos en dichas explotaciones pecuarias. Desconocemos por qué el padrón no incluyó a la población libre de origen africano que radicaba en la urbe. Según consigna el cronista santiaguero Emilio Bacardí hacia 1580 dos negras libres "tocadoras de bandola, una de ellas proveniente de La Española, eran miembros de una la orquesta que tocaba en las iglesias santiagueras. E. Bacardí, Crónicas de Santiago de Cuba, t.I, p.105.

22 Manuel Lucena Salmoral, Leyes para esclavos. El ordenamiento jurídico sobre la condición, tratamiento, defensa y represión de los esclavos en las colonias de la América española. Cdrom Tres grandes cuestiones de la historia de Iberoamérica, Madrid, Fundación MapfreTavera/Fundación Ignacio Larramendi, 2005, p.796.
} 
do tierras "para la siembra del sustento de nuestras familias por cuya causa algunos de los dichos naturales han desamparado y desamparan dicho pueblo y se van a tierras extrañas". ${ }^{23}$ De tal suerte, las posesiones fueron consideradas realengas sobre todo a partir del momento en que "los criollos propietarios de hatos y corrales necesitaron más tierras, debido a la demanda de la producción exportable hacia las colonias extranjeras y también por el crecimiento demográfico de la ciudad y las exigencias del consumo interno". ${ }^{24}$ De ahí que la intención del cacique Rodríguez para que se le señalaran los límites de las tierras asignadas y eventualmente se devolvieran a la comunidad los predios usurpados fracasase rotundamente porque ni a los protectores, por lo general escogidos entre el patriciado criollo, para defenderlos ni al cabildo de Santiago de Cuba -cuyos funcionarios hicieron caso omiso de la carta real enviada en noviembre del propio año 1655 con la orden de restituir lo apropiado-25 les interesó nunca poner fin a la ambigüedad e indefinición en que se mantuvo el derecho al disfrute del territorio del Caney. ${ }^{26}$ Situación agravada cuando, por decisión del propio cacique se iniciaba, en 1657 , el proceso para la erección de una ermita -consagrada a San Luis Obispo de ahí que el poblado se comenzara a conocer por dicho nombre- pues les era "molesto solicitar el pasto espiritual en la ciudad, a dos leguas de distancia", 27 ofreciendo que tanto él como "todos los suyos contribuirían lo necesario a completar los 50.000 maravedíes que en este Obispado tenía cada cura" con el arrendamiento de "algunos pedazos de tierra", resultando que,

23 Olga Portuondo Zúñiga, "Una sublevación de indios en 1758”, en Olga Portuondo Zúñiga, Entre esclavos y libres de Cuba colonial, Santiago de Cuba, Ed. Oriente, p.28. La autora destaca la participación de los indios en las luchas sociales de aquellos años, involucrando también a los llamados cobreros en el real de minas de Santiago del Prado. De manera general, la alianza entre los habitantes originarios de la isla y los esclavos data del inicio de la conquista y colonización pues juntos hicieron frente a la explotación y a la injusticia, aliándose también, sin embargo, también en determinados momentos de la historia, al poder colonial para reprimir a otros grupos de rebeldes.

${ }^{24}$ O. Portuondo Zúñiga, "Una sublevación de indios”, p.30.

25 O. Portuondo Zúñiga, “Una sublevación de indios”, p.29.

${ }^{26}$ En 1774 por orden de la Audiencia de Santo Domingo, fue trazado el primer plano de los terrenos de la comunidad, eran 371 caballerías de tierra, de las cuales el $88,4 \%$ resultaban aprovechadas por diez de los más importantes dones criollos santiagueros. O. Portuondo Zúñiga, "Español o indio: ¿Qué era lo mejor?”, en O. Portuondo Zúñiga, Entre esclavos y libres de Cuba colonial, p.119.

${ }^{27}$ L. A. Baralt, “Apuntes históricos del pueblo”, p.10. 
al paso del tiempo, los antiguos censatarios vecinos de la urbe santiaguera apoyados por el cabildo de la capital oriental que, por demás, comenzó a hacer mercedes de terrenos a los interesados en el próspero cultivo tabacalero- se "alzaron con ellos en calidad de propios".

Ahora bien, para frenar el éxodo de habitantes y fijar a la población tanto en la capital oriental como en los dos núcleos aledaños a ella: El Caney y El Cobre establecido este último a finales del siglo XVI, era necesario crear una estructura defensiva que hiciera frente con éxito a los ataques de ingleses y franceses, ya como parte de expediciones militares, ya de incursiones de corsarios y piratas. ${ }^{28}$ Muestra de ello resultó ser, sin dudas, la experiencia vivida por los vecinos de Santiago de Cuba en 1662 con la toma y destrucción de la ciudad por el célebre corsario inglés Henry Morgan, decidiéndose, finalmente, la corona a invertir recursos en un sistema defensivo que incluyó la reedificación del Castillo del Morro y la construcción del castillejo de La Estrella: conjunto de baterías dispuestas para la defensa de la boca de la bahía. Teniendo El Caney un importante papel en ambas acciones porque fue a dicho poblado donde se desplazó la población civil santiaguera para protegerse de los invasores y porque los naturales residentes en el mismo resultaron empleados, aparentemente bajo coacción, como mano de obra en las labores constructivas..$^{29}$ No obstante, los trabajos emprendidos así como el envío de tropas -provenientes de otros territorios americanos como Nueva España- favorecieron la reanimación económica -la presencia de fuerza de trabajo hizo circular el dinero y estimular el consumo- de la ciudad y su jurisdicción. ${ }^{30}$ De tal suerte que, ya para 1689 , la población de Santiago de Cuba mostraba signos de restablecimiento al contarse en la urbe 3.035 personas agrupadas en 463 familias mientras que en El Caney se registraban 294 habitantes y 60 núcleos familiares. ${ }^{31}$

\footnotetext{
${ }^{28}$ Archivo General de Indias (Sevilla, España) (AGI), Santo Domingo, legajo 136, comunicación al rey sobre la defensa de Santiago de Cuba, 13 de agosto de 1663.

${ }^{29}$ Juan Manuel Reyes Cardero, "De la historia social y constructiva de la fortaleza colonial La Estrella”, en Juan Manuel Reyes Cardero, Santiago colonial: arqueología e historia, Santiago de Cuba, Ed. Santiago, 2008, p.29.

30 Rolando Antonio Pérez Fernández, "El culto a la Guadalupe entre los indios de El Caney", en Del Caribe n. ${ }^{\circ}$ 29, Santiago de Cuba, Casa del Caribe, 1999, p.64.
}

31 O. Portuondo Zúñiga, “Estudio demográfico del Departamento Oriental”, p.42. 
La magnitud del crecimiento experimentado por la capital del Departamento Oriental, se aprecia, sobre todo, a través del proceso de construcción de un sistema de iglesias y plazas que tuvo su origen en el templo catedralicio frente a la Plaza de Armas. Así, encontramos parroquias en las intercepciones de calles como Santa Lucía y Nuestra Señora de los Dolores, erigidas a fines del siglo XVI y en 1722 respectivamente, en explanadas abiertas, como la de Santo Tomás Apóstol, consagrada en 1715, o contiguas a un convento, como la de San Francisco, pero siempre, estratégicamente ubicadas allí, donde se concretaba el asentamiento de vecinos. Fueron, por tanto, las autoridades religiosas -con el aparente y único interés de llevar la instrucción a la comunidad, pero pretendiendo, a la vez, ejercer el control sobre el comportamiento público y privado de los feligreses, distribuir de forma equitativa los ingresos provenientes de los servicios espirituales, y, finalmente, limitar, en lo posible, el desplazamiento de las personas por el área citadina- las primeras en regular la presencia física de los habitantes en el núcleo urbano. Comprendiéndose, entonces, por qué las autoridades civiles, a raíz del empadronamiento de 1778 , tomaron como referencia para su realización la estructura parroquial existente, a saber: el partido de la Catedral y el de Santo Tomás. 32

Sistema que se aplicó paralelamente en los campos de la jurisdicción, al subdividir el territorio en partidos rurales, resultando así unidades administrativas que, aun con poca cantidad de pobladores contaban con núcleos de habitantes más o menos definidos. De tal suerte, para 1757 El Caney -con una extensión de cuatro leguas de largo por una de ancho- era considerado uno de los partidos que, junto a Jiguaní, Tiguabos, Mayarí y El Cobre, formaban parte de la llamada jurisdicción Cuba, superando su población, para el referido año, como lo indican los datos aportados por el obispo Pedro Morell de Santa Cruz en su visita pastoral, los 500 habitantes. Justamente, a dicho funcionario debemos una de las pocas descripciones del poblado indio que ha llegado hasta nosotros, así estamos al tanto de que tenía ocho calles y quince cuadras, que la mayoría de sus casas estaban cubiertas de paja o de yagua, material este último empleado por los indios para cubrir sus bohíos y que el pueblo "siempre ha sido tenido como de Naturales, para el goce de sus Privilegios, sin embargo de ser pocos los

32 Estos dos partidos se dividían a su vez en cuatro cuarteles. Olga Portuondo Zúñiga, iMisericordia! Terremotos y otras calamidades en la mentalidad del santiaguero, Santiago de Cuba, Ed. Oriente, 2014. 
que conservan el Color de su antigua prosapia. Los más de ellos son mestizos. Unos y otros [...] componen ochenta y tres familias y otras tantas casas". ${ }^{33}$ Interesándonos, sobremanera, señalar la atención del interés del prelado por mostrar una población mezclada que no conservaba el "color" indio y que, por tanto, era susceptible a que se le privase de sus derechos, no tomándose el trabajo de separar los habitantes naturales - de los que sin embargo nos dice que era "tan grave su miseria que algunos de ellos viven y mueren bajo los árboles" 34 - de los mestizos, quizás porque consideraba irrelevante dicho dato después de haber afirmado la desproporción entre unos y otros.

No resultando fortuito que el interesado registro de Morell de Santa Cruz hubiera tenido lugar en uno de los momentos de tensión social experimentados por los caneyenses en sus enfrentamientos con los ambiciosos dones santiagueros, que poseían en los alrededores del pueblo 8 trapiches, además de las 75 estancias de cultivo que los vecinos más pobres, blancos y negros, habían fomentado. Así, a pesar de la mediación realizada entonces por el conciliador personaje -permaneció toda una semana en el pueblo predicando y administrando los sacramentos a los "mestizos"- las injusticias acumuladas provocaron que, en mayo de 1758, estallase una rebelión. Por supuesto, el motivo oficial del descontento, informado por el gobernador del Departamento Oriental a su superior en La Habana, distaba mucho de la realidad pues, según el funcionario, el origen del motín, que incluyó el asalto a la cárcel para poner en libertad a varios naturales prisioneros, no era otro que su empeño por reducir a los que se encontraban dispersos "por varios parajes [...] a fin de que cada vecino fabricase casas separadas y estancia que le produjese sus menesteres", ${ }^{35}$ ocultando, de esta manera, a la vez que las usurpaciones y el abandono en el que sobrevivían los que ahora eran llamados ingratos, la represión severa por un piquete de soldados y paisanos que, desde Santiago de Cuba, acudieron a imponer el orden temiendo que, como había sucedido otras veces en el pasado y acontecería en el futuro, indios y esclavos, sobre todo los llamados cobreros - descendientes de los cautivos que, en el siglo XVI, fueron comprados por la Corona para la explotación de

\footnotetext{
33 Pedro Agustín Morell de Santa Cruz, La visita eclesiástica, La Habana, Ed. Ciencias Sociales, 1985, p.115.

${ }^{4}$ P. Agustín Morell de Santa Cruz, La visita eclesiástica, p.116.

${ }^{35}$ ANC, Fondo Correspondencia de los Capitanes Generales, legajo 9, n. ${ }^{\circ} 52$.
} 
las minas en el cercano poblado de El Cobre- se unieran; acción gubernamental que, por supuesto, no incluyó un plan de mejoras de las condiciones que habían dado pie a las protestas pues, en verdad, cualquier acto en dicho sentido hubiese implicado el fortalecimiento de la comunidad, su desarrollo tanto económico como social y, por ende, su supervivencia en el tiempo y no era esta, para nada, la aspiración de los propietarios santiagueros representados en el cabildo y apoyados por los gobernadores.

Con relación a Santiago de Cuba el obispo Morell de Santa Cruz se mostró muy interesado en referir todo aquello que diera testimonio de su esplendor, de ahí la detallada descripción de sus templos y el calificativo de solemne y nunca visto que dio al recibimiento que le hicieron a su entrada, dejando bien en claro que su fin era sacar a "algunos del errado concepto en que (están) en que Cuba es un Villaje, siendo realmente una ciudad", ${ }^{36}$ a la vez que reconociendo las desgracias naturales -terremotos y secas- por las que los vecinos experimentaban con frecuencia falta de provisiones de boca, porque el "comercio nunca ha florecido" en ella ${ }^{37}$ y ofreciendo, con respecto a sus moradores solo cifras globales: 549 familias de blancos, 605 de pardos libres y 265 de negros libres, para un total de 8.118 personas que, sumados a los 3.678 esclavos de todos sexos y edades, resultaban en 11.793 vecinos residentes en una urbe que ya tenía cuarenta y cuatro calles y mil cuatrocientas diez y ocho casas. ${ }^{38}$

La ciudad -que según "algunos parecía un convento espacioso, donde en las calles por el día solo transitaban hombres, curas y monjes-39 tendría que esperar hasta las dos últimas décadas del siglo XVIII para asistir al inicio de un lento movimiento de renovación en su imagen urbana -afectada por los terremotos de 1766 y de $1784^{-40}$ cuando en nuevo gobernador Juan Bautista Vaillant

36 P. Agustín Morell de Santa Cruz, La visita eclesiástica, p.138. El religioso se encarga de aclarar que el nombre de Cuba por si solo o junto con el de la ciudad, bastaba para que todos comprendiesen que se referían a la de Santiago de Cuba y efectivamente así se conoció a la ciudad hasta casi finalizar el siglo XIX.

${ }^{37}$ P. Agustín Morell de Santa Cruz, La visita eclesiástica, p.151.

38 P. Agustín Morell de Santa Cruz, La visita eclesiástica, p.172.

${ }^{39}$ María Elena Orozco Melgar, Génesis de una ciudad del Caribe, Santiago de Cuba en el umbral de la modernidad, Santiago de Cuba, Oficina del Conservador de la Ciudad, 2008, p.41.

40 M. E. Orozco Melgar, Génesis de una ciudad, p.31. Sobre estos dos devastadores terremotos ver O. Portuondo Zúñiga, iMisericordia! Terremotos y otras calamidades, pp.47-70. 
(1788-95), se empeñaría en promover la reconstrucción de los principales edificios gubernativos y la construcción del primer paseo público o alameda, además de transformar internamente la ciudad desde su división en ocho cuarteles. ${ }^{41}$ Vocablo, este último, que -aun cuando nos remite al modelo de ciudad campamento del siglo XV y al carácter de enclave militar en que se había transformado la valiosa colonia- designaba, en realidad, pequeñas unidades administrativas, que hicieron más eficiente el control de los pobladores, para lo cual, se rotularon también las calles y se numeraron las casas. Justo es decir que esta última operación ya se había realizado durante los empadronamientos de 1775 y 1778, tal como se evidencia de las listas elaboradas tanto en los cuarteles santiagueros como en el pequeño centro urbano del Caney pues las calles por entonces trazadas fueron registradas según la tradición popular las había bautizado.

Por su parte, la estructura económica de la jurisdicción la definían tanto las explotaciones pecuarias dado el sistema extensivo de crianza, y las agrícolas como las vegas, estancias y pequeños trapiches, con su producción destinada básicamente al autoconsumo y a la exportación del excedente a las islas vecinas de Jamaica y Saint Domingue donde se desarrollaba con ímpetu el sistema plantacionista. A la vez que la política de monopolio estatal sobre el tabaco -cultivo en el cual tenían los pobladores del Caney experiencia previa a la llegada de los conquistadores- favorecía el establecimiento de vegas de la aromática hoja y, por tanto, el crecimiento de la población libre en la jurisdicción santiaguera.

Un estrecho vínculo histórico existía pues entre los residentes en la capital oriental y los avecindados en el pueblo indio establecido a pocos kilómetros de ella, relaciones que se hicieron más tensas a medida que la elite terrateniente criolla se interesó en "subvertir el sistema económico y cambiar la organización del trabajo con el fin de entrar en la esfera de creación de valores para el mercado internacional". ${ }^{2}$ Tales propósitos impactarían, sin lugar a dudas, tanto en el reflejo que en lo adelante tendrían los naturales residentes en el poblado en los empadronamientos y censos coloniales como en el afán de atribuir la "calidad" de pardo/mulato y/o negro/moreno a la población libre de la ciudad, teniendo en cuenta que el objetivo era limitar en lo posible el ascenso social y el reforzamiento de la estructura estamental, mucho más cuando el equilibrio demográfi-

${ }^{41}$ M. E. Orozco Melgar, Génesis de una ciudad, p.31.

42 O. Portuondo Zúñiga, “Estudio demográfico del Departamento Oriental”, p.68. 
co se vería inclinado hacia la población calificada como "de color" en detrimento de los blancos de origen europeo.

Plano de la ciudad de Santiago de Cuba, 1803

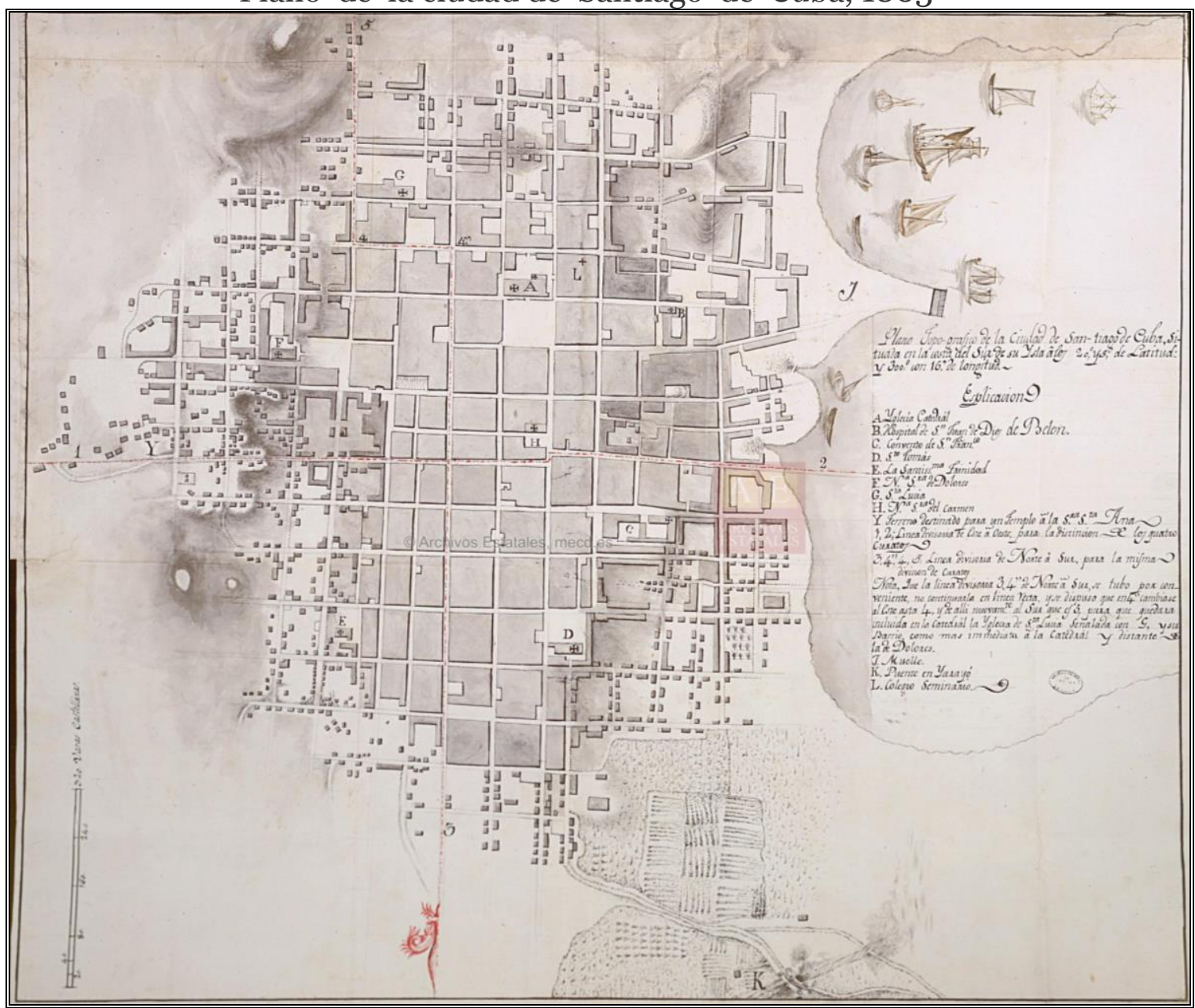

Fuente: AGI, Mapas y Planos, Santo Domingo, exp.643bis. 


\section{De indios naturales a blancos españoles: los padrones de 1775 y 1778 en el pueblo de San Luis del Caney}

Hasta el momento desconocemos cuándo se recibió en la sede del gobierno del Departamento Oriental la orden enviada, desde la capitanía general, para realizar el registro de sus habitantes, tampoco cuándo se iniciaron dichos trabajos tanto en la ciudad de Santiago de Cuba como en sus partidos rurales. Se conoce, no obstante, que el gobernador de la plaza Juan Antonio Ayauz de Ureta dio la tarea a los capitanes pedáneos y que, en el caso del Caney, esta fue encomendada a un tal Pablo Esteban quien dio cuenta del trabajo realizado tanto en el pueblo como en su partido rural en dos cuadernos "formados en el día de la fecha," 1 de septiembre de 1775, en la ciudad de Santiago de Cuba. La frase del funcionario nos lleva a inferir que la información llegada hasta nosotros fue puesta en limpio a partir de los apuntes tomados, pues es materialmente imposible que en una jornada recopilara los datos tanto por la cantidad de hogares existentes en el pueblo como por las instalaciones agrícolas a censar y la dispersión de las mismas: 159 estancias de labor, 20 vegas de tabaco y 7 ingenios de fabricar azúcar.

Tres años después, el 10 de mayo de 1778 daba inicio, ordenado por el obispo Santiago Hechavarría Elguezúa, al levantamiento de un nuevo "Padrón de los habitantes naturales [...] "con la debida distinción de clase, estado y castas de las personas de ambos sexos sin excluir los párvulos". ${ }^{43}$ En este caso ha sido imposible establecer la identidad de los funcionarios que intervinieron en el empadronamiento pero, por el aspecto que ofrecen las listas, enmiendas, tachaduras y varios tipos de letras, es evidente que se trata del trabajo original, es decir, los datos puros que no fueron los remitidos a los superiores. Veamos entonces cuál era la estructura poblacional del partido y sobre todo cuál la imagen que nos transmiten estos dos registros tomados con poco tiempo de diferencia:

${ }^{43}$ AGI, fondo Indiferente General, 1527, comunicación del obispo Santiago J. Hechavarría al Ministro José de Gálvez fechada en La Habana el 8 de septiembre de 1778. 
Tabla 2: Población del Caney y de su área rural (1775-1778)

\begin{tabular}{||l|c|c|c|c|}
\hline \multirow{2}{*}{ Calidad y condición civil } & \multicolumn{2}{c|}{ Pueblo } & \multicolumn{2}{c|}{ Campo } \\
\cline { 2 - 5 } Blancos & 1775 & 1775 & 1775 & 1775 \\
\hline Indios & 21 & 74 & 74 & 21 \\
\hline Pardos libres & 528 & 237 & 237 & 528 \\
\hline Pardos esclavos & 18 & 40 & 40 & 18 \\
\hline Negros libres & 0 & 1 & 1 & 0 \\
\hline Negros esclavos & 1 & 90 & 90 & 1 \\
\hline
\end{tabular}

Fuente: Elaboración propia, ANC, fondo Gobierno General, legajo 489, n ${ }^{\text {os }} .25122$ y 25 123, Fondo Miscelánea de Expedientes, legajo 4074, letra G.

Nuestro primer comentario se dirige a destacar la importancia de la población registrada en 1775 como "india" -cuya imagen se corresponde con hombres y mujeres de poca estatura, pelo muy lacio y negro y poca barba en el caso de los hombres- ya que constituían el 62,9\% de todos los habitantes. Por lo que, las alusiones a una población "mestiza" que realizara el obispo Morell de Santa Cruz se nos muestran más como certidumbre del interés por silenciar la presencia de los naturales que como realidad constatada por el funcionario que optó por ser fiel a lo que "veían" sus ojos y cumplir con las orientaciones recibidas para asignar a cada cual el indicador calidad-color que le correspondía según sus orígenes familiares y rasgos fenotípicos. Resultando significativo, en 1778, sin embargo, la disminución de la presencia de naturales $-53.5 \%$ de todos los residentes en el partido- lo que no consideramos muestra de un alza repentina de la mortalidad ni de un éxodo de familias sino de la manipulación de los datos en cuanto al indicador calidad-color, notándose básicamente cómo, por las correcciones introducidas en el padrón, los individuos antes calificados indios, aparecieron, con posterioridad, reflejados cual pardos libres.

Ahora bien, que la mayoría de los naturales residiesen en el núcleo urbano sí constituye evidencia del poco aprovechamiento que hacían de los recursos naturales asignados para la supervivencia. No obstante, algunas de las ocupaciones económicas que, por entonces, desempeñaban: pescadores y vegueros, son testimonio de la reminiscencia de prácticas ancestrales, ${ }^{44}$ que constituían

\footnotetext{
${ }^{44}$ Algunos pueblos indocubanos eran expertos pescadores y desarrollaron artes que aún se practican. Lourdes Domínguez, Jorge Febles y Alexis Rives, "Las comunidades aborígenes de Cuba", en María del Carmen Barcia, Gloria García y Eduardo Torres-Cuevas (org.), La Colonia, evolu-
} 
aun la base del sostén para muchas familias, mientras que las de monteros y criadores de ganado menor resultaban asociadas a labores introducidas por los españoles. En tal sentido, la concentración en el área rural de la población no india, obsérvese que la constituían mayoritariamente blancos, pardos y negros, libres y esclavos, muestra el éxito que tuvieron los "usurpadores" de terrenos, tolerados en principio gracias al pretexto de producir alimentos para el mercado citadino, luego porque el cultivo de tabaco era interés de la Real Hacienda y, más tarde, porque el azúcar era el producto que más perspectivas mostraba para convertirse en el vínculo de la región con los mercados extranjeros. De tal suerte que, desde las denuncias del cacique Marcos Rodríguez en 1655 hasta el panorama que nos ofrecen los padrones de 1775 y 1778 se constata una realidad que había llegado a un punto irreversible y que, sin dudas, era consecuencia de la desatención sistemática de prevenciones como la dictadas por la Corona en 1618:

conforme a Cédulas Reales ordeno y mando que en pueblos de indios no estén ni resida ningún español, ni mestizo, negro, ni mulato, y especialmente se entienda esto con las mujeres, y más precisamente con los padres y madres, mujeres e hijos, deudos, huéspedes y criados o esclavos del encomendero o doctrinante, so pena de veinte pesos por cada vez que contraviniere, la mitad para el juez que lo sentenciare y la otra mitad para la iglesia del tal pueblo, y si fuere persona baja en cincuenta azotes. ${ }^{45}$

Recordemos, por ejemplo, que, en 1604 solo aparecían indios residiendo en El Caney, resultando evidente que, desde entonces, a las autoridades no les inquietó en lo más mínimo la entrada y permanencia en un pueblo reputado como reserva para naturales, de individuos que no gozaran de dicha calidad. Por supuesto, los "extraños" no se limitaron a establecerse como arrendatarios y labradores pues varios de ellos se unieron con indios/as constituyendo familias que, legitimadas o no por la iglesia, se convirtieron quizás en estrategia de aproximación de los foráneos hacia los legítimos dueños del recurso más importante: la tierra.

ción socioeconómica y formación nacional, de los orígenes hasta 1867, La Habana, Ed. Política, 1994, p.42.

${ }^{45}$ M. Lucena Salmoral, Leyes para esclavos, p.796. 
Adentrándonos entonces en los análisis de las familias debemos precisar que en 1775 fueron registradas 7 parejas mixtas -4 en el pueblo y 3 en el campo- 4 de las cuales la integraban hombres calificados como blancos y 2 como pardos, todos unidos con indias. Mientras que solo 1 indio, Manuel José Biña que, además de registrarse unido con una mujer blanca, Paula Neel, era hermano de Gregoria Biña, también casada con un blanco. Pero lo interesante, en realidad, es cómo el empadronador calificó cual indios/as a todos los descendientes de estas parejas pues, quizás donde algunos veían el "mestizaje," el meticuloso funcionario quiso respetar la preeminencia que otorgaba dicha calidad la que, desde su punto de vista, sería lo suficientemente fuerte como para mantenerse intacta al menos durante la primera generación o que fuese de aquellos convencidos de que dicha calidad, como la condición civil, se transmitía invariablemente por el "vientre" materno -aun cuando en el caso de los Biña-Nel decidiera lo contrario- idea que servía muy bien para obstaculizar las estrategias de blanqueamiento y que fue defendida con firmeza por todos los que tuvieron en sus manos el poder para decidir cuál era la calidad-color legal de una persona a despecho de si su padre era un blanco de limpia sangre. De cualquier manera, que el empadronador considerase indios e indias a los hijos de estas parejas constituía el reconocimiento de una condición que los colocaba, al menos en teoría, en un estado ligeramente superior pues los naturales constituyeron una suerte de escalón intermedio entre los blancos, europeos y criollos y los pardos/mulatos y negros/morenos africanos y criollos y sus descendientes.

Así, a pesar del riguroso trabajo realizado por el funcionario los datos colectados no fueron incluidos en el "Estado general de la isla" de 1775 remitidos a la corte por el gobernador y capitán general Marqués de la Torre, lo que indica que los funcionarios encargados de procesar la información -pudiendo haber tenido en cuenta además los resultados obtenidos en los otros dos pueblos que aún conservaban el carácter de reservas de naturales: San Pablo de Jiguaní y Guanabacoa, este último ubicado en la jurisdicción de la Habana-46 la despreciaron por estimarla poco significativa. Resultando difícil determinar, además, en cuál "clase" fueron agregados los más de quinientos indios caneyenses pues, en el citado resumen, solo se ofrece, de manera global, la información sobre

${ }^{46}$ Lamentablemente no se han conservado los datos de los empadronamientos de dichos pueblos correspondientes a 1775. Para Jiguaní disponemos únicamente del padrón general "con la expresión de la edad, estado y ejercicio de cada vecino" realizado en 1783 por el capitán del partido. ANC, fondo Miscelánea de Expediente, legajo 4074, letra U. 
blancos, mulatos y negros, libres y esclavos, residentes en la jurisdicción Cuba, inclinándonos a creer que, antes que admitirlos entre los blancos, por su "mestizaje", lo hicieran en el grupo llamado "de color".

Por su parte, el registro de 1778 -que al igual que el precedente tomaba al hogar como unidad censal, distinguiéndose a los agregados que convivían con la familia principal, consignando, además, detalles como los materiales de las viviendas (en la mayoría de los casos el guano y, en menor medida, la paja) y a su clasificación, desde el punto de vista tipológico, en rancho y casas- contiene variaciones formales que denotan una visión diferente sobre la calidad de los vecinos. Cambiando, eso sí, la nomenclatura indio/a empleada en 1775 por la de natural. ${ }^{47}$ Lo más interesante de este padrón resultan ser, entonces, las tachaduras y enmiendas realizadas sobre el registro original, sugiriendo la diferencia de tinta y de letra que el trabajo inicial fue rectificado, con aparentes "correcciones", por otro funcionario que no solo se limitó a tachar la calificación de natural otorgada a aquellos hombres y mujeres, ${ }^{48}$ presentándolos como blancos/as, como se puede apreciar en el registro del hogar de los Biña-Neel sino que "asignó" la calidad-color a los hijos de las parejas mixtas con un criterio que no favorecía ni al "blanqueamiento" ni a la "naturalización" de los habitantes de la comunidad. De manera que, en las 12 familias que tuvieron sucesión -de las 21 constituidas por hombres pardos y mujeres naturales (12 en la ciudad y 9 en el campo) identificadas esta vez en las listas- su descendencia fue calificada desde la calidad del padre, no atribuyendo, por el contrario, dicha calidad a la mayoría de los hijos de las parejas formadas por hombres blancos y mujeres naturales (ver nuevamente hogar de los Biña-Neel) pues de las 13 familias que se muestran en el padrón desde esta tipología, en solo 2 se clasificó a los hijos como sus padres. Mereciendo una referencia especial los nacidos de padres naturales y mujeres pardas pues, en las 2 únicas familias de este tipo apreciamos que solo los varones fueron designados "blancos" como su progenitor mientras que a las hembras se les asignó la calidad de sus madres. A la vez que, en la familia cons-

${ }^{47}$ Fue esta la calificación empleada por el funcionario que realizó el empadronamiento de 1783 antes citado en el poblado indígena San Pablo de Jiguaní.

48 A todas luces, el funcionario estaba más interesado en la asignación de la calidad-color y en "ocultar" la presencia de foráneos en el poblado que debemos esforzarnos para reconocer, debajo de las rayas, los nombres de localidades cubanas como Bayamo, Jiguaní o Sancti Spíritus o extranjeras como Islas Canarias y Campeche de las que procedían los que se establecieron en la comunidad. 
tituida por un hombre moreno y una india, la hija aparece reflejada como parda, quizás porque el taimado burócrata decidió considerar a su madre como "blanca”.

Tabla 3: Familia Biña-Neel, 1775-1778

\begin{tabular}{|l|l|}
\hline \multicolumn{1}{|c|}{1775} & \multicolumn{1}{|c|}{1778} \\
\hline $\begin{array}{l}\text { Calle de San Luis: } \\
\text { Manuel José Biña, 36 años, casado, indio, } \\
\text { estanciero. }\end{array}$ & Calle de San Luis: \\
Su mujer Paula Neel, 28 años, casada, blanca. & Blanco \\
Casa de Tejas 57 de Manuel Viña, 40 años, & casado, natural, vega. \\
Hijo: & Paula Neel su mujer, 37 años, blanca de Cuba \\
Andrés José Biña, 7 años, soltero, indio. & Hijos: \\
Hijas: & Andrés José de 11 años, soltero, con su padre. \\
Mariana Micaela Biña 3 años, india. & Juan, 1 año. \\
María Dolores Biña 1 año, india. & Hija: \\
& Mariana 11 años \\
& Agregado blanco a dicha casa: \\
& Dn. Francisco Tomás Saldivar Pres. 32 años, \\
& Sacristán Mayor \\
& Ana María Hernández, 60 años, viuda blanca \\
de Cuba. & Hijo: \\
& Tomás Neel, de 22 años, soltero, blanco, ve- \\
& guero \\
\hline
\end{tabular}

Fuente: Elaboración propia, ANC, Fondo, Gobierno General, legajo 489, no. 25 122, Fondo, Miscelánea de Expedientes, legajo 4074, letra G.

Observemos ahora el modo de proceder del funcionario a través de lo acontecido con la familia Domínguez-Almenares: 
Tabla 4: familia Domínguez-Almenares, $1775-1778$

\begin{tabular}{|c|c|}
\hline 1775 & 1778 \\
\hline $\begin{array}{l}\text { Calle San Luis: } \\
\text { Basilio Domínguez, } 45 \text { años, casado, indio, } \\
\text { estanciero. } \\
\text { Su mujer Anastasia Almenares, } 46 \text { años, casa- } \\
\text { da, india, estanciera. } \\
\text { Hijos: } \\
\text { Pablo José Domínguez, } 19 \text { años, soltero, indio, } \\
\text { estanciero. } \\
\text { Tomás Domínguez, } 14 \text { años, soltero, indio, } \\
\text { estanciero. } \\
\text { Ferminiano Domínguez, } 8 \text { años, soltero, indio, } \\
\text { estanciero. } \\
\text { Hijas: } \\
\text { Bárbara Petrona Domínguez, } 15 \text { años, soltera, } \\
\text { india, } \\
\text { estanciera. } \\
\text { Rita María Domínguez, } 3 \text { años, soltera, india. }\end{array}$ & $\begin{array}{l}\text { Calle San Luis: } \\
\text { Rancho de paja } 64 \\
\text { pardo } \\
\text { Basilio Domínguez, } 51 \text { años, casado, natural, } \\
\text { mayoral. } \\
\text { Anastasia Almenares, su mujer, 48, blanca, } \\
\text { natural. } \\
\text { Hijos pardos: } \\
\text { Pablo José, } 21 \text { años, soltero, trabaja con su } \\
\text { padre. } \\
\text { Juan, } 18 \text { años, soltero, trabaja con su padre. } \\
\text { Tomás Matías, } 13 \text { años, soltero, trabaja con su } \\
\text { padre. } \\
\text { Hijas pardas: } \\
\text { Bárbara, } 20 \text { años, soltera. } \\
\text { Rita María, } 7 \text { años, soltera. } \\
\text { María Eusebia } 4 \text { años. }\end{array}$ \\
\hline
\end{tabular}

Fuente: Elaboración propia. Observación: la calificación de pardo fue agregada con una letra diferente, lo que sugiere que fue realizada con posterioridad al empadronamiento del hogar.

Basilio y Anastasia transitan de indios a naturales, calidad que, en el caso del primero, es sustituida o enmendada para ser más exactos, por la de pardo que transmite, por obra y gracia del empadronador, a sus hijos quienes, hasta entonces, eran indios como la madre, práctica que resultaba coherente con la descendencia matrilineal propia de las comunidades indocubanas. Operación que fue realizada en los casos de parejas mixtas y, en general, para todos los residentes en el poblado, no llevándose a cabo, sin embargo, con el cuaderno de los "habitantes que se haya[ban] en los campos del partido, en sus ingenios, vegas y estancias”, cuyas listas no resultaron manipuladas, pecando, en todo caso aquí, por omisión al no referir las dotaciones de esclavos de los ingenios, lo que explica la disminución en cifras de dicho grupo que se aprecia en la Tabla 2 entre un padrón y otro. Debiéndose, quizás, la diferencia en el tratamiento de la información, en primer lugar, a que una parte de quienes laboraban en dichas explotaciones agrícolas eran cautivos y en segundo, a que, se trataba también de individuos libres que residían, de modo permanente, en la ciudad de Santiago 
de Cuba, como se advierte de la frase "existe en Cuba". ${ }^{49}$ Así lo común era que se registrara - con sus respectivas calidades de blanco, pardo y moreno- el nombre del propietario de la instalación agrícola, el de la persona que se encontraba a cargo, como mayoral o arrendatario y el de los esclavos.

Resulta, sin embargo, toda una sorpresa descubrir que tan laborioso cambio de calidad de indio/a a natural y de esta a la de blanco, no se mostró, de igual manera, en las estadísticas de los residentes en el poblado:

Tabla 5: Habitantes en San Luis del Caney en 1778

\begin{tabular}{|c|c|c|c|c|c||}
\hline \multicolumn{2}{|c|}{ Blancos } & \multicolumn{2}{c|}{ Pardos y Negros libres } & \multicolumn{2}{c|}{ Pardos y Negros esclavos } \\
\hline Hombres & Mujeres & Hombres & Mujeres & Hombres & Mujeres \\
\hline 19 & 8 & 413 & 387 & 7 & 1 \\
\hline
\end{tabular}

Fuente. Elaboración propia. Observación: entre los hombres blancos se incluyen tres religiosos. AGI, Fondo, Indiferente General, 1527.

Información que, enviada al rey en septiembre de 1778 por conducto del obispo de Cuba como el "Estado general de los habitantes de la diócesis [...] formado con las divisiones, distinciones y separaciones prevenidas por S.M.", desmintió desde el pomposo título el acatamiento de la orden, al incluir a los indios "blancos" del Caney como pardos y morenos. Ahora bien, si sucedió de igual manera con el "Estado general de la isla de Cuba" ${ }^{0}$ de 1775 debemos preguntarnos ¿̇cuál era el objetivo del o los empadronadores y de los funcionarios correspondientes al manipular la calidad-color de la comunidad india? En el caso del empadronamiento de 1775 parece claro que existía un interés por conocer el monto de una población de la que, posiblemente, no se tuvieran datos exactos desde la visita pastoral de 1757. Dudamos, sin embargo, que el fin último de reflejar la calidad-color de indio/a fuera informar al rey porque, para la

${ }^{49}$ Efectivamente, en el padrón de 1778 de la ciudad de Santiago de Cuba, se dice labrador en tierras del Caney.

50 Según el investigador Rolando Antonio Pérez Fernández, en dicho censo y en los siguientes empadronamientos, los indios fueron incluidos en el número de blancos, no demostrando, sin embargo, su afirmación pues, en verdad, la información que se ofrece en el censo de 1775 es general para toda la jurisdicción Cuba. "El culto a la Guadalupe", p.65. 
élite santiaguera como para la habanera con respecto a la reserva indígena de Guanabacoa, era conveniente que, en el centro metropolitano, no se tuvieran noticias fidedignas sobre un segmento de la población residente en la isla que, si bien no tenía mucha relevancia desde el punto de vista demográfico, sí lo tenía desde el simbólico dada la "protección" que, como vasallos predilectos de la Corona, disfrutaban, al menos en teoría. Por su parte la decisión de asignar, en el padrón de 1778 , la calidad de blanco a los naturales y, finalmente, su inclusión en el estamento de los llamados "libres de color" resulta coherente con la ideología que sustentaba el patriciado santiaguero, de manera que el criollismo que los distinguía de los españoles, también excluía al elemento indio porque resultaba ser un obstáculo para sus planes de fomento azucarero y de la agricultura comercial en su más amplio sentido. De modo tal que el mestizaje fue uno de los caminos para la "desaparición" de los primitivos dueños de los recursos naturales del país, por lo que, atribuir la calidad de "pardos" a los hijo/as de las indias no debe considerarse un proceder ingenuo o fruto del azar. Siendo esta la manera desde la cual una joven llamada Caridad Díaz, nieta e hija de la "blanca" Cecilia Montoya y del pardo Antonio Montoya según el registro de 1778, se vería repudiada por el joven que le había dado palabra de matrimonio cuando su abuelo demostró a aquel que Caridad "era nieta de un chino o negro esclavo que fue de Don Prudencio Díaz" y que siendo ellos descendientes de "indios legítimos, limpios de mala raza y buenos cristianos" no podían unirse a quien "Desc(endía) de servil condición”. ${ }^{51}$ Logrando, muchos años después -al informar a la reina Isabel II que la "raza india" de Cuba se había extinguido- los intereses de la oligarquía criolla y los de la Real Hacienda imponerse con un feliz resultado: la privatización sin cuestionamientos y reclamos de los fértiles terrenos que los naturales nunca llegaron a poseer de manera efectiva y provechosa para su supervivencia como grupo. 52

\footnotetext{
${ }^{51}$ ANC, fondo Audiencia de Santiago de Cuba, legajo 817, n. ${ }^{\circ}$ 19.077, El indio del Caney, Silverio Montoya, abuelo de Tomás Almenares se opone al matrimonio que este piensa contraer con Caridad Díaz. 1802.

52 ANC, fondo Intendencia de Hacienda, legajo 393, n. ${ }^{\circ} 18$. Expediente sobre la solicitud del Ayuntamiento del pueblo del Caney a que se conceda a las familias de verdadera raza de Indios que en él existen, una suerte de tierra de las que se han incorporado a la Corona. 1849.
} 


\section{De pardos/morenos a blancos: familia y calidad en Santiago de Cuba}

El llamado padrón general de 1778 constituye para la ciudad de Santiago de Cuba el primero de su tipo de que se conservan copias en archivos cubanos. Los sucesivos empadronamientos realizados -habida cuenta de las pérdidas y deterioros sufridos en este importante acervo documental- demuestran que registrar a la población -casa por casa en todos los cuarteles e incluso mediante listas de extranjeros- se convirtió en instrumento de control gubernamental. Empeño que se vinculó estrechamente con el rápido crecimiento demográfico experimentado en el territorio de la jurisdicción de Cuba en la última década del siglo XVIII pero, sobre todo, con el hecho de que la población parda y negra, al margen de su condición civil, sobrepasase, en el último tercio de dicha centuria, a la blanca en el conjunto de los avecindados en la ciudad.

Tabla 6: Habitantes de la ciudad de Santiago de Cuba (1778-1791)

\begin{tabular}{|l|c|c|}
\hline \hline Calidad y condición civil & $\mathbf{1 7 7 8}$ & $\mathbf{1 7 9 1}$ \\
\hline Blancos & 4.536 & 14.090 \\
\hline Pardos y negros libres & 3.901 & 20.735 \\
\hline Pardos y negros esclavos & 3.787 & 8.986 \\
\hline Total & 12.224 & 43.811 \\
\hline
\end{tabular}

Fuente: Elaboración propia. AGI, Fondo Indiferente General, 1527 y AGI, Fondo Cuba, 1434.

Tendencia que se muestra justamente desde la comparación de los padrones de 1778 y 1791. Así, cuando en aquel los blancos constituían el 37\%, los libres de color el $32 \%$ y los esclavos el $31 \%$, en el último la proporción cambiaba de manera notable con 32\%, 47\% y $21 \%$ respectivamente. ${ }^{53}$ Estructura demográfica que se fundamenta en la conjugación de dos importantes hechos: la

53 Tasa de crecimiento que se mantendría, más menos, hasta pasada la sexta década del siglo XIX, a raíz del decrecimiento de la fuerza de trabajo esclava por la incapacidad de los hacendados de reponer la pérdida por causas naturales o por venta hacia otras regiones más desarrolladas. 
apertura, en 1789, del comercio de esclavos, que en un inicio se limitó a las colonias extranjeras del Caribe y luego se expandió a las costas de África y la llegada, a partir de 1791, de "esclavos ladinos y criollos junto a sus amos blancos desde el Guarico", ${ }^{4}$ como antesala de la inmigración masiva de colonos, negros y mulatos libres, desde Saint Domingue, entre 1798-1803. Situación esta última que propiciaría un clima de intranquilidad social con sus respectivas medidas como respuesta -conceder permiso de entrada únicamente para los esclavos bozales y prohibir los típicos festejos de mamarrachos así como el encargo, a los funcionarios que debían velar por el orden interno en los cuarteles y barrios citadinos de la realización de empadronamientos, útiles tanto para detectar a "todo forastero sin oficio o que residiese en la ciudad sin algún motivo honesto" 55 para su expulsión, como para conocer la composición y calidad de las familias "francesas" que se acogían a la soberanía española- con el objetivo de preservar del "contagio" revolucionario al territorio jurisdiccional.

De tal suerte, a partir del modelo empleado en 1778 para registrar los habitantes de los hogares -que consignaba los indicadores: nombre, edad, sexo, calidad y ejercicio- se derivaron los utilizados para los empadronamientos de 1797 y de 180o. Imprimiéndole, por supuesto, cada funcionario, al registro que elaboraba, su peculiar manera de entender las indicaciones recibidas. Ejemplo de lo cual resulta el hecho de que, en 1778, en los dos cuadernos que se conservan de los cuatro que debieron realizarse atendiendo a que era ese el número de cuarteles o barrios que, por entonces, existían en la ciudad, el indicador calidadcolor se consigne de manera diferente: en uno marcando la generalidad desde la frase "casa de" blancos, pardos y morenos y en otro refiriendo la individualidad tal como se había orientado; mientras que, en los tres cuadernos de que disponemos para 1797 correspondientes al sexto y séptimo cuartel y a la calle Ancha, los empadronadores optaron por registrar a blancos, pardos y negros siguiendo dicho orden jerárquico pero en listas independientes, método no asumido -

\footnotetext{
54 Olga Portuondo Zúñiga, "La inmigración negra de Saint-Domingue en la jurisdicción de Cuba (1798-1809)", en O. Portuondo Zúñiga, Entre esclavos y libres, p.61.

55 ANC, fondo Asuntos Políticos, Legajo 6, n. ${ }^{\circ}$ 4, Bando de Buen Gobierno dictado por el Coronel Juan Nepomuceno Quintana, Gobernador y Capitán de Guerra, Santiago de Cuba, 27 de febrero de 1796. El gobernador encargaba a "los Alcaldes de Barrio, para que cel[aran] en sus respectivos cuarteles, la puntual observancia de este artículo y d[ieran] cuenta así mismo al gobierno, de los vagos y gente de mal vivir que [supieran residían] en esta ciudad".
} 
según podemos observar en el cuaderno del octavo cuartel, único conservado-56 por el agente que elaboró el padrón de 1800 en el que se consignaría el dato solo para el cabeza de familia y los agregados. En tal sentido, debemos indicar que, si los funcionarios, pudieron dar fe de la información que proporcionan las uniones mixtas en cada padrón, se debió a que, por entonces, no existían las medidas legales que se dictaron a partir de 1778 con el fin de impedir que personas consideradas "desiguales" se unieran legítimamente. ${ }^{57}$ Sin lugar a dudas, en una urbe que se ennegrecía con el paso de los años, además de la limpieza de sangre, el apego a conceptos como hidalguía y preeminencia así como al lustre que daba proceder de una familia de "antigua nobleza",58 la obsesión por la calidad-color se apoderó del patriciado santiaguero como la mejor defensa y/o contención encontrada por la elite ante los esfuerzos y estrategias que desplegaron algunas familias para "blanquearse".

Nuestras primeras consideraciones tienen como sustento los registros de la familia Rodríguez-Ramos:

Tabla 7: Familia Domínguez-Ramos, 1778-1797

\begin{tabular}{|c|c|c|}
\hline 1778 & 1797 & 1797 \\
\hline $\begin{array}{l}\text { Calle San Francisco: } \\
\text { Casa } 1419 \text { de blancos } \\
\text { Don Pedro Ramos, } 60 \text { años, } \\
\text { labrador en tierras de San Luis, } \\
\text { su mujer: María de Torres, parda. } \\
\text { Hija: } \\
\text { María de la Encarnación } \\
\text { Ramos, virgen. } \\
\text { Agregados: } \\
\text { José de Torres, } 30 \text { años, } \\
\text { carpintero } \\
\text { Francisco Mena, } 25 \text { años } \\
\text { jornalero, miliciano. }\end{array}$ & $\begin{array}{l}\text { Cuartel 6: } \\
\text { Lista de los blancos } \\
\text { Casa de Don José Rodríguez, } \\
\text { casado, } 36 \text { años. } \\
\text { Su mujer: } \\
\text { Encarnación Ramos, } 36 \text { años. } \\
3 \text { hijos de } 1 \text { a } 7 \text { años. } \\
4 \text { hembras de } 14 \text { a } 16 \text { años } \\
\text { Agregados: } \\
\text { María Ramírez, viuda, } 50 \text { años. } \\
\text { Con su hija soltera, } 25 \text { años. }\end{array}$ & $\begin{array}{l}\text { Cuartel 6: } \\
\text { Lista de los blancos } \\
\text { Casa de Don Félix Ramos, } \\
\text { labrador, casado, } 30 \text { años. } \\
\text { Su mujer Doña Ángela } \\
\text { Guerra. } \\
2 \text { hijas hembras de } 1 \text { a } 7 \text { años. } \\
\text { Agregados: } \\
\text { Miguel Guerra, labrador, } \\
\text { soltero, } 30 \text { años }\end{array}$ \\
\hline
\end{tabular}

Fuente: Base de datos de familias reconstruidas (1778-1861).

56 Advertimos que, en todos los casos, se trata de los documentos que han sobrevivido al paso del tiempo y a las pérdidas.

${ }^{57}$ En mayo de 1810, desde la capitanía general, se le orientó al gobernador de Santiago de Cuba que no diera su autorización para el matrimonio de un soldado blanco con una morena libre. ANC, fondo Asuntos Políticos, legajo 211, n. ${ }^{\circ} 70$.

58 L. Provencio Garrigos, Sobre la construcción de género, p.211. 
Obsérvese que, en 1778, al empadronador no le resultó un problema el consignar que Don Pedro estaba casado con una parda -a juzgar por los cálculos que hemos realizado debieron contraer matrimonio cuando él había cumplido los cuarenta años mientras que ella, si no atenemos a los patrones de nupcialidad de la época, debió ser más joven- como tampoco al registrador de 1797 -a pesar de que había optado por separar a los residentes en su demarcación de acuerdo a la calidad-color- le fue difícil incluir a Encarnación Ramos en la lista de los vecinos blancos del sexto cuartel. ¿̇Influiría en la decisión del funcionario el hecho de vivir muy cerca de los Rodríguez-Ramos? Es probable, como también que, por esa misma razón, no anotara la calidad parda de la mujer, sin llegar al exceso de otorgarle el tratamiento de Doña con el que aparecería registrada trece años después en el padrón de $1810 .{ }^{59} \mathrm{Y}$, aun cuando era más difícil para los hijos varones de las parejas mixtas, conseguir un enlace que diera continuidad al blanqueamiento constatamos en el propio registro de 1797 que Félix Ramos -hermano menor de Encarnación y ausente en el hogar de 1778 por no haber nacido- aparece considerado como Don al estar unido a una mujer blanca,

\footnotetext{
${ }^{59}$ Esta es la inscripción realizada del hogar de los Rodríguez-Ramos en 1810 Calle San Félix. Casa de D. José Rodríguez, casado, 49 años. Su mujer Doña Encarnación Ramos, 49 años. Hijos: José Rafael, 22 años. José Ángel, 18 años. Félix Saturnino, 14 años. José María, 8 años. Ramón5 años. María Dolores, 13 años. Margarita, 3 años. Comensales: Don Félix Ramos, viudo, 42 años. Da María Ramírez, viuda, 74 años. Da. Dolores Ramos, soltera, 35 años. Esclavos: 5 varones y 4 hembras. ( 1 hembra casada). Mayoral Ignacio Tomaso, negro libre, francés, soltero, 50 años. Observamos que en los padrones, el tratamiento de Don se reservó a las personas de cierto relieve y no para todos los blancos; digamos que no era usual que a los niños se les asignara, pero cuando estos eran hijos de padres distinguidos aunque tuvieran meses de nacido se les anteponía a sus nombres el Don o Doña, quizás para recalcar su preeminencia. Dicho tratamiento tuvo una evolución muy interesante en la América española, ya que en España estuvo por siglos reservado a los caballeros, a los nobles e hijosdalgos. Hemos observado que, probablemente desde finales del siglo XVIII, en Cuba y en otras colonias se comenzó a emplear para todos los blancos, con la declarada intención de distinguirlos de las personas de otro color; dándose a entender con ello que quien lo portaba no era de África ni descendiente de africanos. En 1801, una Real Cédula dispuso que quien desease gozar del distintivo de Don debía pagar 1400 reales. ANC, fondo Gobierno Superior Civil, legajo 351, $\mathrm{n} .{ }^{\circ} 12.854$. Expediente sobre el tratamiento de Don a los escribanos y procuradores. 1850. Tal práctica alcanzó su apogeo en el XIX, y en Cuba se haría extensiva formalmente a toda la población, en 1893, gracias a la demanda expuesta por los representantes de las sociedades de pardos y morenos de la isla de Cuba en la Asamblea que los reunió en La Habana en 1892. Oilda Hevia Lanier, "Otra contribución a la historia de los negros sin historia”, en Debates Americanos n. ${ }^{\circ}$, La Habana, Universidad de La Habana, 1997. pp.87-88.
} 
tener dos hijas y residir a unas veinte casas de los parientes que habrían de acogerle en su viudez. ${ }^{60}$

Resultando lo más interesante a destacar cómo, a pesar de que Encarnación no fue calificada nunca, al menos en los padrones aquí examinados, como blanca, en sentido general y desde su ejemplo, las evidencias indican que fue la unión legítima de mujeres pardas y morenas con un blanco, el primer "requisito" para que los registradores otorgaran el color blanco a las primeras y el pardo a las segundas. Encontrándonos en el primer caso a la familia RodríguezCisneros:

Tabla 8: Familia Rodríguez-Cisneros, 1778-1800

\begin{tabular}{|c|c|}
\hline 1778 & 1800 \\
\hline $\begin{array}{l}\text { Calle Ancha: } \\
\text { casa } 1397 \text { de blancos. } \\
\text { Don Manuel Rodríguez, } 33 \text { años, oficial de } \\
\text { junta. } \\
\text { Su mujer Rafaela Cisneros, parda. } \\
\text { Hijos: } \\
\text { Félix José Rodríguez, } 8 \text { años, escuela. } \\
\text { Miguel José Rodríguez, } 7 \text { años, escuela. } \\
\text { Manuel de Jesús Rodríguez, } 2 \text { años. } \\
\text { Hijas: } \\
\text { María Josefa Rodríguez. } \\
\text { María Teresa. } \\
\text { María Caridad. } \\
\text { Esclava: María del Carmen carabalí. }\end{array}$ & $\begin{array}{l}\text { Calle San José: } \\
\text { De dicha casa del Coronel Don Bartolomé } \\
\text { Morales vive: } \\
\text { El blanco Don Manuel Rodríguez, Escribiente, } \\
54 \text { años. } \\
\text { Doña Rafaela Cisneros, su esposa, } 50 \text { años. } \\
\text { Cuatro hijos de } 1,12,18 \text { y } 24 \text { años } \\
\text { y tres hijas de } 10,20 \text { y } 22 \text { años. }\end{array}$ \\
\hline
\end{tabular}

Fuente: Base de datos de familias reconstruidas (1778-1861).

Llama la atención que Don Manuel haya accedido a unirse legítimamente con una parda teniendo en cuenta que no era un simple labrador como Don Pedro o un blanco pobre como otros que, identificados en nuestros estudios empleando el enlace como un medio de acceder a las propiedades de sus esposas de "color"61 pues se trata, en este caso, de un empleado que, en pocos años, alcan-

${ }^{60}$ ANC, fondo Miscelánea de Expedientes, Legajo 4.076, Letra R. Padrón nominal de habitantes del sexto cuartel de la ciudad de Santiago de Cuba, con expresión de edad, estado y calidad. 1797.

${ }^{61}$ En 1841, la parda Inés Pereira, natural de Santiago de Cuba, se presentó a juicio de divorcio contra su esposo, en el mismo declaraba: "fui casada el 12 de agosto de 1824, con dispensa, con 
zaría una plaza de escribano, ejercicio para el cual se exigía limpieza de sangre. Se nos ocurre pensar entonces que quizás la parda fuese hija natural de un don santiaguero que se ocupó de posicionarla, matrimonio mediante, en una esfera ligeramente superior a la que estaba destinada por su procedencia materna ya que así solían actuar los criollos blancos, algunos incluso pertenecientes a distinguidas familias, ${ }^{62}$ que no se tomaban muy a pecho las rígidas convenciones sociales. De cualquier modo, Rafaela, como otras mujeres en su misma situación, fue reconocida, al menos en los padrones, con la calidad de blanca que se aprecia en el de 1800 y aunque no fue la única parda casada con un blanco que

Juan de Vega, hombre blanco natural de Canarias, intervino en la ceremonia Don José Antonio Díaz del Castillo capellán de la fortaleza militar San Pedro de la Roca, celebrada esta en casa de Úrsula María Castellón”. Archivo Histórico Provincial de Santiago de Cuba (Santiago de Cuba, Cuba) AHPSC, fondo, Juzgado de Primera Instancia, legajo 3161/2, n. ${ }^{\circ} 6$. Los detalles aportados por Pereira nos indican las dificultades que tuvo que vencer para legalizar el enlace, así, a pesar de recibir la dispensa, debió celebrar la ceremonia privadamente y por un párroco que no ejercía en ninguna de las parroquias de la ciudad. Declarando, además que su esposo había recibido por dote más de 12 mil pesos, atractiva suma que "compensó" a Vega por casarse con una parda criolla. La pareja, al parecer, no tuvo descendencia pues no se habla de ella en el expediente.

${ }^{62}$ En marzo de 1794 se daban las proclamas nupciales en la Catedral santiaguera del matrimonio que contraerían el blanco Don José Antonio Cos y Doña María del Rosario Hechavarría, hija natural del entonces difunto regidor Don José Antonio Hechavarría, habida con la parda Rosalía Ramos Castellanos, sin embargo, en el documento leído ante los distinguidos feligreses no se mencionó a la progenitora de la novia. Dada la notoriedad del hecho, los regidores acordaron que el distintivo de Don que se había empleado para distinguir a la joven era un "abuso y corruptela voluntariamente ejercitado por el difunto regidor cuando repugna a la naturaleza de su madre, que es ella y toda su estirpe mulatos, provenientes de los esclavos de la distinguida familia de los Barretos" y que dicha proclama no era testimonio de la verdad, por lo que para "desimpresionar al vulgo" sugirieron que, en las proclamas que restaban, no se le titulase con el don, para "evitar otros progresos que tal vez con disimulo de este asunto, se promoverían con perjuicio de las jerarquías". Por entonces, otra hija de la Ramos intentaba contraer matrimonio con Don José Antonio Veranes, enlace al que se opuso su legítimo padre promoviendo un expediente de disenso e informativo para demostrar que aquella era mulata. Los sinsabores de los elitistas regidores santiagueros continuaron pues, en julio del propio año, recibieron una Real Cédula que disponía que los expósitos fuesen considerados hijos legítimos ya que el rey asumía su paternidad, mandato que protestaron por los "inconvenientes que pueden ocasionarle a las familias de distinción de esta ciudad por la variedad de castas y calidades que se hallan en esta jurisdicción de negros, mulatos y mestizos, que se valdrán de aquel asilo para colocar a sus hijos en los mejores enlaces y empleos". Finalmente, en 1796, los regidores no tuvieron más opción que acatar la voluntad de Carlos IV de legitimar y, de paso, blanquear a las hijas pardas del difunto Hechavarría. E. Bacardi, Crónicas de Santiago, tomo I, pp.248-251 y 259. 
encontraría el registrador en su recorrido por el cuartel,63 decidió distinguirla solo a ella de dicha manera, asignándole, incluso, el digno tratamiento de Doña. ${ }^{64}$

Tabla 9: Parientes Cortés-Herrera, 1778-1800

\begin{tabular}{|c|c|c|}
\hline 1778 & 1800 & 1800 \\
\hline $\begin{array}{l}\text { Calle de San Isidro: } \\
\text { Casa } 1042 \\
\text { Francisco Gregorio Cortés-45 años- } \\
\text { casado- veedor de tabaco- blanco. } \\
\text { Su mujer Dominga Herrera, parda. } \\
\text { Hijo: } \\
\text { Rafael Emigdio, } 12 \text { años-soltero, } \\
\text { labrador, pardo. } \\
\text { Hijas: } \\
\text { Francisca Antonia, soltera, parda. } \\
\text { Margarita, soltera, parda. } \\
\text { María Nicolasa, soltera, parda. } \\
\text { María Celedonia, soltera, parda. } \\
\text { María Catalina, soltera, parda. } \\
\text { María Rafaela, soltera, parda. } \\
\text { Morenos esclavos: } \\
\text { Francisco Antonio, } 30 \text { años, soltero. } \\
\text { Juan Nepomuceno, } 8 \text { años. } \\
\text { Morena esclava: } \\
\text { María Dolores, casada. } \\
\text { Agregados: } \\
\text { Leonardo Herrera, } 40 \text { años, soltero, } \\
\text { Labrador, pardo. } \\
\text { Pedro Herrera, } 30 \text { años, soltero, } \\
\text { Labrador, pardo. } \\
\text { Luisa Herrera, soltera, parda. } \\
\text { Teodora Herrera, soltera, morena. } \\
\text { Josefa Herrera, viuda, parda. }\end{array}$ & $\begin{array}{l}\text { Calle de San Gerónimo: } \\
\text { Lista de los blancos } \\
\text { Casa de D. José Carvajal, propieta- } \\
\text { rio de } 30 \text { años. Su esposa Catarina } \\
\text { Cortés de } 24 \text { años. Una hija de } 2 \\
\text { años. } \\
\text { Casa contigua: } \\
\text { Casa: el pardo Francisco Gregorio } \\
\text { Cortés, hacendado, viudo- } 55 \text { años. } \\
4 \text { hijas de } 20,25,27 \text { y } 30 \text { años. } 3 \\
\text { nietos de } 2,3 \text { y } 4 \text { años. } \\
1 \text { nieta de } 2 \text { años. } \\
\text { Esclavos: } 9 \text { negros de } 12,15,20,22 \text {, } \\
24,25,26 \text { y } 30 . \\
\text { Y } 4 \text { negras esclavas de } 12,25,27 \text { y } \\
30 \text { años. }\end{array}$ & $\begin{array}{l}\text { Calle de San Carlos: } \\
\text { Lista de los pardos } \\
\text { Casa de Teodora Herrera, } 31 \\
\text { años,propietaria, } 1 \text { hijo de } 2 \\
\text { años. } \\
\text { parda Luisa Herrera,viuda, } \\
\text { propietaria, } 45 \text { años } \\
2 \text { hijos de } 13 \text { y } 14 \text { años. } \\
2 \text { hijas de } 18 \text { y } 20 \text { años. } \\
\text { También: Antonio José Concha, } \\
\text { herrero, } 34 \text { años. } \\
\text { Su esposa Isabel Angulo, } 23 \\
\text { años. } \\
3 \text { hijos varones de } 3,4 \text { y } 6 \text { años. }\end{array}$ \\
\hline
\end{tabular}

Fuente: Base de datos de familias reconstruidas (1778-1861).

${ }^{63}$ Hemos seguido a varias de las parejas mixtas que identificamos en 1778 y sólo a la Cisneros, la inscriben, en 1800 , como blanca. Sin dudas, fue esta una deferencia hacia su familia por parte del alcalde del cuartel donde residían.

${ }^{64}$ Sin embargo, al enviudar regresó a su calidad de parda como lo comprobamos en la inscripción de 1810: Calle del Matadero Principal. Casa: de Rafaela Cisneros, parda, viuda, de 56 años. Hijos blancos: Félix Rodríguez de 36 años, Anselmo de 20 años, Pedro de 11 años, Caridad de 26 años, María Dolores de 22 años y María del Rosario de 17 años. Esclavos: 2 varones y 1 hembra. Indicamos, finalmente, que un hijo, Félix, no obstante la impureza de su sangre, accedió al oficio de escribano, profesión que estuvo expresamente vedada a los mulatos y sus descendientes. 
Por otra parte, tenemos un excelente ejemplo de la ascensión desde la calidad de morena a la de parda y luego a la de blanca, ascenso que, sin embargo, solo fue posible para una rama de la parentela Cortés-Herrera (ver la anterior tabla).

El padre, Francisco Gregorio Cortés, fue calificado como "blanco" en 1778, probablemente por su empleo en la Real Factoría de Tabacos para controlar a los vegueros. ${ }^{65}$ Por su parte, Dominga Herrera, la esposa, había sido criada como expuesta en la casa de Don José de Herrera, a quien se le atribuía la paternidad de aquella, fruto de su relación con una esclava negra llamada Prudencia. ${ }^{66}$ Es presumible entonces, que Don José arreglara el matrimonio de su hija con el Cortés, un pardo, casi blanco, que en consideración a su desahogada posición económica y el contingente de esclavos que poseía, era calificado como hacendado en 1800.67 En este registro, sin embargo, el mismo funcionario que unas calles antes había inscrito como blanca a Rafaela Cisneros, ${ }^{68}$ guarda silencio sobre la calidad de la esposa de Don Vicente del Valle Carvajal, Catalina Cortés. La casa, habitada por ambos, formaba parte del colgadizo propiedad de Gregorio quien, de seguro, desglosó una pieza para dársela, como dote, a su

${ }^{65}$ El puesto de que disfrutaba Francisco Gregorio era algo así como un intermediario entre los vegueros y la Factoría, ya que los veedores eran los encargados de establecer las calidades de las hojas de tabaco y las categorías y pesos de las cosechas, de lo que dependía la cantidad pagada a los cultivadores. Quizás él mismo poseía una vega de tabaco, obsérvese que tanto su hijo como los hombres agregados que residían con él, eran labradores.

${ }^{66}$ En 1823, Catalina Cortés se atrevió a promover un informativo para demostrar que sus padres "Gregorio y Dominga Herrera y todos sus descendientes, fueron tenidos por personas blancas, limpias de toda mala raza de negros y mulatos y por tales han gozado de este concepto en lo público y la nominada mi madre ha estado en el mismo predicamento de blanca como hija natural que fue de D. José de Herrera, habida con Prudencia Herrera, la misma que en calidad de expuesta criaron y educaron en la casa del expresado D. José de Herrera y por esta razón todos sus descendientes son reputados por personas blancas:" ANC, fondo Audiencia de Santiago de Cuba, legajo 895, no. 31 347. Información producida por Catalina Cortés, para acreditar su limpieza de sangre y la de sus mayores. 1823 .

${ }^{67}$ Cortés era el mayor propietario de esclavos del octavo cuartel, sólo Don Manuel Bestard y Don Antonio de Jaen se le acercaban, con diez cautivos cada uno. Era, además, el único pardo hacendado, calificativo que, entre sus convecinos, merecieron siete hombres y cinco mujeres blancos. ANC, Fondo Miscelánea de Expedientes, legajo 4075, Letra Ak, Padrón que manifiesta los moradores del octavo cuartel de la ciudad de Santiago de Cuba con expresión de sexo, edad, clase, estado y oficio. 1800.

${ }^{68}$ Ambas familias residían en el octavo cuartel. 
primera hija casada con un blanco. ${ }^{69}$ Intentaba Cortés, con esta tenue distancia física entre los domicilios, marcar la diferencia entre la familia blanca de Catalina y el resto de sus hermanas pardas domiciliadas con él. Pudiéndose constatar, años después, cómo los afanes del padre se tradujeron en el calificativo de blancos y el tratamiento de don que recibieron sus nietos, sin lograr escapar, no obstante, de la discriminación como lo evidencia el que las hijas de Catalina permanecieran sin contraer matrimonio y la salida del varón de la ciudad, huyendo quizás de los prejuicios que públicamente señalaba a la parentela como descendientes de una negra esclava. ${ }^{70}$ Observándose también como Teodora Herrera, la única de las hermanas de Dominga que, en 1778, resultaba calificada como morena, ascendía, en 1800, a la calidad de parda, sin que logremos explicarnos la condescendencia del registrador a no ser que la consideración de "propietaria" a pesar de no existir en el padrón indicios de sus bienes, fuera suficiente o porque convivía con su hermana Luisa a quien, al parecer, había "recogido" en su viudez pues, en ocasiones, la presencia de un individuo de calidad diferente al del cabeza de hogar bastaba para que tal indicador se le atribuyera al resto de sus integrantes.

Finalmente, el cambio de la calidad de pardo/a a moreno/a fue al que menos pudimos dar seguimiento, lo que, nos permite algunas precisiones. La primera, sugerida por la existencia de familias mixtas; así cuando en un padrón el hombre era descrito como pardo y la mujer como morena, en el siguiente la clasificación se homogenizaba pero siempre hacia la calidad considerada "inferior". ${ }^{71}$ La segunda, relacionada con el vecindario donde vivía la persona; de modo que residir entre pardos y morenos podía "ennegrecer" a blancos pobres y a pardos de cierta solvencia. Un tal Domingo Zamora, por ejemplo, fue identificado como pardo en 1778 y en 1800 como "negro libre", debido seguramente

\footnotetext{
${ }^{69}$ Colgadizo: La casa baja, cuyo techo tiene una sola corriente, ya se considere independiente, ya unida a algún edificio. Esteban Pichardo, Diccionario provincial casi razonado de vozes y frases cubanas, La Habana, Ed. Ciencias Sociales, 1985, p.173. En Santiago de Cuba, este tipo de vivienda fue asociado a las clases más desposeídas y edificadas, generalmente anexas a una casa principal, destinándose a ganar alquiler.

${ }^{70}$ ANC, fondo Audiencia de Santiago de Cuba, legajo 66, n. ${ }^{\circ}$ 1.614, Intestado de Catalina Cortés. 1848.

${ }^{71}$ De modo que podemos inferir que en el descenso influyó dicha circunstancia y que a los pardos/as unidos a morenos/as les era difícil retener su calidad, al contrario de lo que sucedía con los blancos que elegían tener relaciones con una mujer de otro color.
} 
tanto a su matrimonio con la morena libre María Caridad Febo como a su larga permanencia en el barrio de Santo Tomás. ${ }^{72}$

Así, el examen de los padrones santiagueros desde el prisma de la evolución de las familias y los hogares demuestra que, más allá del factor subjetivo, la asignación de la calidad-color tenía un estrecho vínculo con factores como las relaciones personales y la mayor o menor proximidad a los círculos del poder; aun cuando este poder estuviese personificado en un simple alcalde de barrio que podía ser a su vez el empadronador, personaje que al fin y al cabo no era tan insignificante ya que tenía la potestad para decidir el "color" de los residentes en la demarcación cuya "vigilancia" se le había encargado. Claro, la solvencia económica también tenía su parte en el ascenso cromático, como lo atestigua el caso de Gregorio Cortés, sin embargo no todos los pardos de posición relativamente desahogada podían presumir de blancos, en principio porque la vía ideal para el blanqueamiento, el matrimonio, estuvo fuera del alcance para las personas consideradas desiguales a partir de la extensión de la Real Pragmática sobre matrimonios de 1778 a los territorios de ultramar y de una serie de autos acordados por la Real Audiencia de Puerto Príncipe con igual fin..$^{73}$ De hecho, uno de los mayores peligros que acechaban a quienes intentaron continuar adelantando en calidad-color era justamente la aspiración de casarse con un blanco "de sangre pura" ya que durante las investigaciones de los parientes que se oponían al enlace se revisaba la genealogía familiar e invariablemente solían encontrarse los "muertos," contaminados con la esclavitud, que desmentirían la "supuesta" calidad. Por lo que, aunque se le reconociera a pardos y morenos el uso del Don, siempre que intentaran traspasar los límites, se encontrarían con la oposición de aquellos que preferían apartar del hogar a un hijo antes que permitir que el lustre de la familia se empañara por un enlace con alguien que, a todas luces, pasaba por blanco/a pero que no lo era.

\footnotetext{
${ }^{72}$ Santo Tomás fue un típico barrio de gente humilde, allí residieron varios de los hombres y mujeres que "perdieron" su calidad de pardos de un padrón a otro.

${ }^{73}$ ANC, fondo Audiencia de Santiago de Cuba, legajo 1098, n. ${ }^{\circ} 37.241$, Diligencias de disenso al matrimonio que pretende D. Juan Bautista Hechavarría con la parda Felipa Cardoso. 1801, y legajo 1158, n. ${ }^{\circ}$ 39.271. Recurso de Candelaria Sabatela quejándose del despojo que se le ha hecho por el Tribunal Eclesiástico de su hija María de la Concepción so pretexto del matrimonio con el moreno José Antonio esclavo del Regidor D. Pablo Betancourt. 1809. Para un análisis de estas normativas remitimos a Verena Stolcke, Racismo y sexualidad en la Cuba colonial, Madrid, Alianza Ed., 1992, pp.37-41.
} 


\section{Conclusiones}

El presente artículo constituye apenas un punto de partida en el propósito de observar más allá de las cifras y las realidades económicas que suelen mostrarnos los padrones coloniales. Sin dudas, la historiografía cubana debe y puede intentar nuevas lecturas de tales fuentes pues tienen mucho que decir sobre las prácticas sociales vigentes en los momentos en que fueron producidas, lecturas, más que nada, de los márgenes y las enmiendas para descubrir e interpretar los cambios así como las ideas que subyacen en las expresiones y/o clasificaciones empleadas por los empadronadores.

Así, los padrones de 1775 y 1778 del pueblo indio del Caney nos han servido para abordar una nueva faceta de la poco divulgada historia de cómo la elite blanca criolla "extinguió" a los descendientes de los primeros habitantes de la isla para, de esa manera, tener libre acceso a las tierras que por mandato real les pertenecían a los naturales. De modo que la diferencia entre lo ejecutado por los empadronadores y lo informado oficialmente a España frustró, por decirlo de alguna forma, el fin último de los reformadores borbónicos con el objetivo de acceder a los "conocimientos y las herramientas necesarias para el buen gobierno." "Buen gobierno" que no podía ejercerse sobre una realidad escamoteada, siendo posible que muy pocos burócratas del Consejo de Indias supieran quiénes eran aquellos indios que se hacían llamar regidores en la queja enviada a Carlos IV relatando las penurias y los despojos que sufría la comunidad. Por otra parte, la manera en la que el texto original del padrón de 1778 fue reelaborado demuestra que no existía rigidez en la aplicación del indicador calidadcolor -como bien se aprecia a su vez en los padrones de Santiago de Cuba- pues este se aplicaba de acuerdo a los intereses políticos de las elites locales, a fin de cuentas si el empadronador se alejaba de las "orientaciones" recibidas, también prestaba atención a los estados de ánimo del grupo que detentaba el poder en un momento determinado.

Así mismo, al dar seguimiento a las familias y a los hogares constatamos que la calidad-color asignada respondía, tanto a los planes y estrategias individuales de movilidad social, como a las circunstancias en las que se realizaba el

${ }^{74}$ S. P. Solano, "Padrones de población", p.161. 
empadronamiento, resultando decisivas las relaciones que se tuvieran con el funcionario y la voluntad de aquel por cumplir fielmente el trabajo que se le había encomendado. En tal sentido, podemos indicar la sugerente diferencia apreciada entre el proceder del empadronador que en El Caney se dedicó con paciencia digna de mejor causa a calificar de pardos a los hijos/as de las parejas mixtas tomando por guía la calidad paterna y el llevado a cabo por parte de los empadronadores de los cuarteles santiagueros que tomaron como referente para el mismo fin a las madres que trasmitirían, en este caso, el color a sus hijas -lo que reservó a las mujeres una misión que, al fin y al cabo, tendía a limitar cualquier estrategia de movilidad ascendente en el sensible tema de la calidadcolor- mientras los varones lo recibirían de su progenitor. De esta manera, ni de la unión de una india con un pardo resultaría un "natural" ni de la de un pardo y una morena, otro pardo, por lo que no todos los descendientes de una misma pareja mejorarían su calidad-color. ${ }^{75}$ De haber seguido un proceder diferente, cuestiones que no estaban en los planes de dominación de la elite criolla, los naturales nunca se hubieran "extinguido" vía mestizaje y Santiago de Cuba se hubiera "blanqueado" en pocos años. Hacer la historia de pueblos e individuos implica también la indagación de las representaciones simbólicas de los colectivos llegadas hasta nosotros pues razonar objetivamente sobre un orden social opresivo e intolerable, significa también estudiar cómo se construyó y cómo se fue transformando hasta agotar sus posibilidades.

\footnotetext{
${ }^{75}$ Una parte importante de las causas de disenso matrimonial que hemos localizado en el Archivo Nacional de La Habana, en el fondo Audiencia de Santiago de Cuba, tienen como protagonistas a padres y otros familiares de pardos/as que se opusieron al enlace de estos con individuos calificados como morenos. La parda Lucía Orozco se niega al matrimonio de su hija con el negro Ubaldo de Vera, pues a pesar de haber sido desflorada por este, Vera era un "sujeto de semejante calidad, que tiene manera que son propias de bozales." Razones parecidas aducía el abogado de Vera, Don Francisco Mancebo, para destacar la inocencia de su defendido; según sus palabras, este no tenía idea del delito que había cometido, pues era, ni más ni menos, que "un individuo rústico, de suma ignorancia, un negro infeliz, que ni escribir y leer sabía", en suma "un bozal". ANC, Audiencia de Santiago de Cuba, legajo 540, n. ${ }^{\circ} 12.565$. Testimonio de los autos seguidos en el Tribunal Eclesiástico por Lucía Orozco, parda, contra Joseph Ubaldo de Vera por lo que de ellos consta. 1791. Valga decir que nuestras observaciones respecto al rechazo familiar hacia las uniones de pardos/as y morenos/as, fundamentadas en la consulta de expedientes localizados en los fondos Audiencia de Santiago de Cuba, Miscelánea de Expedientes y Escribanías de la ciudad de La Habana, no difieren de las conclusiones de la historiadora Verena Stolcke sustentadas en el análisis de dieciséis casos (de un total de 107), en los que quedó claro que la oposición se debía a la diferencia de calidad antes apuntada. Stolcke, Racismo y sexualidad en la Cuba colonial, pp.152-154.
} 


\section{Bibliografía}

\section{Fuentes primarias:}

Archivo General de Indias. (AGI), fondos: Indiferente General; Cuba; Santo Domingo.

Archivo Nacional de Cuba. (ANC), fondos: Audiencia de Santiago de Cuba; Miscelánea de Expedientes; Intendencia de Hacienda; Gobierno Superior Civil; Gobierno General; Correspondencia de los Capitanes Generales.

Archivo Histórico Provincial de Santiago de Cuba (AHPSC), fondo Juzgado de Primera Instancia.

\section{Fuentes secundarias:}

Baralt, Luis Alejandro, "Apuntes históricos del pueblo de indios de San Luis de los Caneyes", en Emilio Bacardí, Crónicas de Santiago de Cuba, tomo II, Barcelona, Tip. Carbonel y Esteva, 1909, pp.7-18.

Carvajal López, David, La población en Bolaños, 1740-1848: dinámica demográfica, familia y mestizaje, Zamora, El Colegio de Michoacán, 2009.

Domínguez, Lourdes, Jorge Febles y Alexis Rives, "Las comunidades aborígenes de Cuba", en María del Carmen Barcia, Gloria García y Eduardo TorresCuevas, (comps.) La Colonia, evolución socioeconómica y formación nacional, de los orígenes hasta 1867, La Habana, Ed. Política, 1994, pp.557 .

García, Gloria, Serrano, Violeta, Tamayo, Irma y Borroto, Alejandrino, Fuentes estadísticas para la historia económica y social de Cuba 1760-190o, La Habana, Ed. Academia, 1987.

Hevia Lanier, Oilda, "Otra contribución a la historia de los negros sin historia", en Debates Americanos n. ${ }^{\circ}$, La Habana, Universidad de La Habana, 1997, pp.87-88.

Ibarra Cuesta, Jorge, "Del sentimiento de patria a la conciencia de nación (1600 y 1868)", en Jorge Ibarra Cuesta, Patria, etria y nación, La Habana, Ed. Ciencias Sociales, 2007, pp.1-82. 
Jouve Martín, José Ramón, Esclavos de la ciudad letrada. Esclavitud, escritura y colonialismo en Lima (1650-170o), Lima, Instituto de Estudios Peruanos, 2005 .

Lucena Salmoral, Manuel, Leyes para esclavos. El ordenamiento jurídico sobre la condición, tratamiento, defensa y represión de los esclavos en las colonias de la América española. CD-Rom Tres grandes cuestiones de la historia de Iberoamérica, Madrid, Fundación Mapfre-Tavera y Fundación Ignacio Larramendi, 2005.

Martínez Alcubilla, Marcelo, Diccionario de la Administración española, peninsular y ultramarina, tomo X, Madrid, Imprenta de la Sra. V. e Hijas de A. Pañuelas, 1869.

Meriño, María de los Ángeles y Perera, Aisnara, Familias, agregados y esclavos. Los padrones de vecinos de Santiago de Cuba (1778-1868), Santiago de Cuba, Ed. Oriente, 2011.

Miranda Saborit, Leo Cesar, Santiago de Cuba (1515-155o), Santiago de Cuba, Ed. Oriente, 1995.

Morell de Santa Cruz, Pedro Agustín, La visita eclesiástica, La Habana, Ed. Ciencias Sociales, 1985.

Novoa Betancourt, José, Haciendas ganaderas en Holguín, 1545-1867, Holguín, Ed., Holguín, 2008.

Orozco Melgar, Maria E., Génesis de una ciudad del Caribe, Santiago de Cuba en el umbral de la modernidad, Santiago de Cuba, Oficina del Conservador de la Ciudad, 2008.

Pichardo, Esteban, Diccionario provincial casi razonado de vozes y frases cubanas, La Habana, Ed. Ciencias Sociales, 1985.

Portuondo Zúñiga, Olga, Santiago de Cuba desde su fundación hasta 1868, Santiago de Cuba, Ed. Oriente, 1996.

Portuondo Zúñiga, Olga, "Una sublevación de indios en 1758, en Olga Portuondo Zúniga, Entre esclavos y libres de Cuba colonial, Santiago de Cuba, Ed. Oriente, 2003, pp.27-34. 
Portuondo Zúñiga, Olga, "La inmigración negra de Saint-Domingue en la jurisdicción de Cuba (1798-1809)", en en Olga Portuondo Zúñiga, Entre esclavos y libres de Cuba colonial, Santiago de Cuba, Ed. Oriente, 2003, pp.58-96.

Portuondo Zúñiga, Olga, "Estudio demográfico del Departamento Oriental. Siglos XVI-XIX (hasta 1868"), en El Departamento Oriental. 1510-1868: dos temas de historia económica, Santiago de Cuba, Ed. Santiago, 2012, pp.31-107.

Portuondo Zúñiga, Olga, iMisericordia! Terremotos y otras calamidades en la mentalidad del santiaguero, Santiago de Cuba, Ed. Oriente, 2014.

Pérez Fernández, Rolando Antonio, "El culto a la Guadalupe entre los indios de El Caney", en Del Caribe n. ${ }^{\circ}$ 29, Santiago de Cuba, Casa del Caribe, 1999, pp.62-73.

Provencio Garrigós, Lucía, Sobre la construcción de género: mujeres, sociedad y educación en Santiago de Cuba, 1778-1868, Tesis doctoral, Universidad de Murcia, Servicios de Publicaciones, 2002. [CD-Rom]

Reyes Cardero, Juan Manuel, "De la historia social y constructiva de la fortaleza colonial La Estrella”, en Juan Manuel Reyes Cardero, Santiago colonial: arqueología e historia, Santiago de Cuba, Ed. Santiago, 2008, pp.25-39.

Solano, Sergio Paolo, "Padrones de población e historiografía sobre la configuración socio-racial hispanoamericana del siglo XvIII", en El Taller de la Historia vol.5, ${ }^{\circ}{ }^{\circ}$, Cartagena, Universidad de Cartagena, 2013, pp.125178.

Stolcke, Verena, Racismo y sexualidad en la Cuba colonial, Madrid, Alianza Ed., 1992. 